DOI: $10.12797 /$ Politeja.13.2016.43.13

Kamil MROCZKA

Państwowa Wyższa Szkoła Zawodowa w Oświęcimiu

Ministerstwo Finansów

kamil.mroczka@gmail.com

\title{
PRAWNE I ORGANIZACYJNE \\ UWARUNKOWANIA SYSTEMU \\ ODPOWIEDZIALNOŚCI CZŁONKÓW \\ KORPUSU SŁUŻBY CYWILNEJ W POLSCE
}

ABSTRACT Legal and organizational conditions of a system of liability of members of the civil service in Poland

The main aim of this article is to present and discuss the fundamental aspects of selected types of liability of the civil service members. Responsibility, as a rule, consists of the use of punitive sanctions i.e. the penalties for violation of: the rules laid down in specific obligation-imposing laws and regulations, the principles of community life (especially in the context of vague quantifiers like sufficiently good repute) and rules of conduct defined by the concept of dignity of the office. There is no doubt that the possibility of responsibility reflects on the performance of the civil servants. Legal regulations concerning various types of liability are therefore primarily aimed at taking care of the public interest and realization of tasks of the State in accordance with applicable laws. Under the current legal regime governing the sphere of responsibility of the members of the civil service, responsibility/liability can be divided into the following types: disciplinary, criminal, material and financial for a blatant violation of the law or a breach of public finance discipline.

Słowa kluczowe: służba cywilna, odpowiedzialność dyscyplinarna, odpowiedzialność karna, odpowiedzialność majątkowa, odpowiedzialność za naruszenie dyscypliny finansów publicznych, odpowiedzialność materialna

Keywords: civil service, disciplinary liability, criminal responsibility, financial liability, responsibility for a breach of public finance discipline, material liability 


\section{WPROWADZENIE}

Fundamentalną cechą każdego systemu administracji publicznej jest to, że swoje działania opiera na aktywności zatrudnionych w niej pracowników. W rozwiniętych państwach demokratycznych kluczowe zadania państwa realizowane są przez neutralnych politycznie, bezstronnych i profesjonalnych pracowników służb cywilnych. Prawzoru dla funkcjonowania służby cywilnej jako elementu systemu administracji należy szukać w starożytnych Chinach. To właśnie w Państwie Środka wykształciła się nowa grupa społeczna, którą stanowili urzędnicy podlegający wyłącznie cesarzowi. Do pełnienia tej służby poszukiwano osób najbardziej uzdolnionych oraz posiadających odpowiednie predyspozycje osobowościowe i intelektualne. Cesarz T’ai-tsung w VII w. n.e. szczycił się, mówiąc: najlepszych i najambitniejszych towię w swoje sieci ${ }^{1}$.

W literaturze przedmiotu, zarówno polskiej, jak i obcojęzycznej, a także w popularnych encyklopediach i słownikach prawniczych termin „służba cywilna” bywa definiowany w różny sposób. Wynika to przede wszystkim z różnorodnych uwarunkowań kulturowych, historycznych, społecznych, gospodarczych i prawnych, w których powstawały i ewoluowały poszczególne systemy polityczne i administracyjne ${ }^{2}$. Według Jolanty Itrich-Drabarek stużba cywilna to wyodrębniony zespót ludzi zatrudnionych na podstawie prawa, $w$ celu realizacji określonych $w$ prawie zadań, kierujących się określonym systemem norm, wartości i procedur, majacych za zadanie stuzyć spoteczeństwu oraz utrzymywać istotne funkcje panstwa $a^{3}$. Znawca problematyki służby cywilnej Grzegorz Rydlewski definiuje tę instytucję jako gwaranta profesjonalnego i lojalnego obsługiwania zmieniających się politycznych ekip rządowych przez urzędników administracji publicznej ${ }^{4}$. Zdaniem autora stużba cywilna to systemowo, prawnie, instytucjonalnie i organizacyjnie wyodrębniony zespót ludzi zatrudnionych na podstawie specjalnej pragmatyki zawodowej $w$ celu realizacji zadań państwa, w ramach obowiazujacych przepisów prawa, kierujących się określonym systemem norm etycznych i moralnych, mających za zadanie stużyć obywatelowi w sposób bezstronny, rzetelny, profesjonalny, neutralny politycznie i efektywny, zarówno pod kątem finansowym, jak i czasowym.

W Polsce służba cywilna stanowi element szerszego systemu administracji publicznej. Jak zauważa Wojciech Zieliński, w prawodawstwie nie istnieje legalna definicja omawianego terminu ${ }^{5}$. Służba cywilna posiada co prawda konstytucyjne umocowanie, co wzmacnia

1 Ping-Ti Ho, The Ladder of Success in Imperial China. Aspects of Social Mobility 1368-1911, New York 1962, s. 258, za: J. Itrich-Drabarek, Uwarunkowania, standardy i kierunki zmian funkcjonowania stużby cywilnej $w$ Polsce na tle europejskim, Warszawa 2010, s. 19.

2 Zob. szerzej: K. Mroczka, Wptyw polityki zarządzania zasobami ludzkimi w stużbie cywilnej na funkcjonowanie państwa, Warszawa 2015, s. 31 i nast. oraz przywołana tam literatura.

3 J. Itrich-Drabarek, Uwarunkowania, standardy..., s. 36.

4 G. Rydlewski, Stużba cywilna w Polsce. Przegląd rozwiązań na tle doświadczeń innych państw i podstawowe akty prawne, Warszawa 2001, s. 13.

5 W.Zieliński, Kierunki zmian systemu zarządzania zasobami ludzkimi w stużbie cywilnej, „Zarządzanie Zasobami Ludzkimi” 2010, nr 6, s. 31. 
jej znaczenie w systemie organów państwowych, niemniej instytucja ta w Polsce nie posiada oczekiwanej stabilności. Na przestrzeni ostatnich dwóch dekad ustawa o służbie cywilnej była zmieniana czterokrotnie. Analizując działania kolejnych rządów, można zauważyć brak spójnej polityki państwa w odniesieniu do służby cywilnej. Większość ekip politycznych traktowała ją na wzór dziewiętnastowiecznego „systemu łupów” i rozpoczynała budowę własnego systemu, na podstawie swoich kryteriów jakościowych i ilościowych.

Od marca 2009 r. obowiązuje Ustawa z dnia 21 listopada 2008 r. o służbie cywilnej6. Nie wchodząc w szczegółowe analizy przepisów, należy podzielić pogląd wielu praktyków i teoretyków, że ustawa ta daje możliwość zbudowania profesjonalnego aparatu urzędniczego państwa polskiego. Co prawda wiele rozwiązań wymaga dostosowania pod kątem wyzwań, jakie stoją przed administracją publiczną, jednak jest to zjawisko naturalne w dynamicznym otoczeniu instytucjonalnym i prawnym oraz społeczno-gospodarczym. Zdaniem autora kadry urzędnicze służby cywilnej (i szerzej - administracji publicznej) należy traktować jako strategiczny potencjał państwa polskiego, gdyż urzędnicy odpowiadają za szereg istotnych zadań wpływających na poziom bezpieczeństwa obywateli jako zbiorowości i państwa jako podmiotu na międzynarodowej arenie gospodarczej i politycznej.

Na gruncie danych statystycznych służba cywilna w Polsce to ponad 120 tys. pracowników (zatrudnianych na umowy o pracę) i urzędników (zatrudnianych na podstawie mianowania) realizujących kluczowe zadania państwa w ponad 2300 urzędach $^{7}$. Zadania te obejmują różne wymiary funkcjonowania państwa, poczynając od prac legislacyjnych, przez działania kontrolne i wykonawcze, na walidacji i prognozowaniu kończąc.

Jak często podkreśla się w literaturze, służba cywilna odgrywa szczególną rolę w administracji rządowej, a realizowane przez nią zadania wymagają rzetelności i wysokiego poziomu kompetencji pracowników w niej zatrudnionych ${ }^{8}$. Nie ulega wątpliwości, że sprawnie działający system służby cywilnej stanowi fundament społeczeństwa obywatelskiego i demokratycznego państwa prawnego. System ten musi jednak podlegać zmianom, tak aby odpowiadał na coraz nowsze wyzwania i potrzeby obywateli.

Zasadniczym celem niniejszego artykułu jest zaprezentowanie i omówienie podstawowych aspektów wybranych rodzajów odpowiedzialności członków korpusu służby cywilnej. Najogólniej rzecz ujmując, odpowiedzialność (z różnych tytułów i ustaw) polega na stosowaniu sankcji typu represyjnego, tj. kar za naruszenie obowiązków przewidzianych w poszczególnych ustawach i przepisach wykonawczych, zasad współżycia społecznego oraz reguł postępowania wyznaczonych pojęciem godności lub powagi urzędu. Nie ulega wątpliwości, że odpowiedzialność oddziałuje w sposób istotny na wykonywanie obowiązków przez pracowników służby cywilnej. Unormowania prawne dotyczące różnego typu odpowiedzialności mają więc na celu dbanie o interes publiczny i realizację zadań państwa zgodnie z obowiązującymi przepisami.

Ustawa z dnia 21 listopada 2008 r. o stużbie cywilnej, Dz.U. 2014, poz. 1111, z późn. zm.

Sprawozdanie Szefa Stużby Cywilnej o stanie stużby cywilnej i realizacji zadań tej stużby w 2013 roku, Kancelaria Prezesa Rady Ministrów, Warszawa, marzec 2014, s. 5.

8 E. Śmigielska, Reforma systemu wynagradzania w korpusie stużby cywilnej, „Zarządzanie Publiczne” 2010, nr 3(11), s. 57. 
W obowiązującym reżimie prawnym regulującym sferę odpowiedzialności członków korpusu służby cywilnej można wyróżnić następujące rodzaje odpowiedzialności: dyscyplinarną ${ }^{9}$, karną, majątkową za rażące naruszenie prawa czy też za naruszenie dyscypliny finansów publicznych i materialną (cywilną).

\section{ODPOWIEDZIALNOŚĆ DYSCYPLINARNA W SŁUŻBIE CYWILNEJ}

Dość powszechnie uważa się, że jedną z cech charakteryzujących służbę cywilną jest reżim odpowiedzialności dyscyplinarnej ${ }^{10}$. Kwestie wynikające z tego rodzaju podejścia zawarte są w rozdziale 9 Ustawy o służbie cywilnej oraz w Rozporządzeniu Prezesa Rady Ministrów z dnia 9 kwietnia 2009 r. w sprawie postępowania wyjaśniającego i postępowania dyscyplinarnego w służbie cywilnej ${ }^{11}$. Jak podkreśla Jacek Jagielski, odpowiedzialność dyscyplinarna - aczkolwiek spotykana w odniesieniu do wielu jeszcze innych grup zawodowych - stanowi jeden z istotniejszych (i charakterystycznych) elementów sktadowych catej konstrukcji stużby cywilnej ${ }^{12}$. Stanisław Kasznica pisał przed kilkudziesięciu laty, że na straży należytego spetniania przez urzędnika obowiązów stużbowych stoi odrębnie skonstruowana odpowiedzialność stużbowa (dyscyplinarna) ${ }^{13}$. Jak już wspomniano, istotą odpowiedzialności dyscyplinarnej są sankcje typu represyjnego, tj. kary za naruszenie obowiązków członka korpusu służby cywilnej, a także reguł postępowania wyznaczonych pojęciem godności lub powagi urzędu albo zawodu (określonych normami stosunku służbowego) oraz reguł wykonywania zawodu określonych normami zawodowej sztuki i etyki ${ }^{14}$.

Zgodnie z art. 113 przywołanej powyżej ustawy zarówno pracownik, jak i urzędnik mianowany odpowiadają dyscyplinarnie za naruszenie obowiązków członka korpusu służby cywilnej. Zdaniem Jacka Jagielskiego strona przedmiotowa odpowiedzialności dyscyplinarnej określona została przez ustawodawcę dość zdawkowo. Określenie czynu zagrożonego karą dyscyplinarną (deliktu dyscyplinarnego) odbywa się bowiem w oparciu o nieprecyzyjne pojęcie „naruszenie obowiązków członka korpusu służby cywilnej”. Ustawodawca nie podjął nawet próby określenia typów czynów zagrożonych karą

9 Członkowie korpusu służby cywilnej nie podlegają odpowiedzialności porządkowej przewidzianej w Kodeksie pracy.

10 M. Gubała, Ł. Paszka, O niektórych proceduralnych aspektach odpowiedzialności dyscyplinarnej w stużbie cywilnej, „Przegląd Prawa Publicznego” 2012, nr 12, s. 54. Tamże o formie prawnej rozstrzygnięć podejmowanych w postępowaniu wyjaśniającym i dyscyplinarnym, prawnoprocesowej funkcji zawiadomienia o wszczęciu postępowania wyjaśniającego, postępowaniu dowodowym, zakończeniu postępowania wyjaśniającego i dodatkowych czynnościach rzecznika w postępowaniach dyscyplinarnych.

11 Rozporządzenie Prezesa Rady Ministrów z dnia 9 kwietnia 2009 r. w sprawie postępowania wyjaśniajacego i postępowania dyscyplinarnego w stużbie cywilnej, Dz.U. 2009, nr 60, poz. 493.

12 J. Jagielski, K. Rączka, Ustawa o stużbie cywilnej. Komentarz, Warszawa 2010, s. 408.

13 S. Kasznica, Polskie prawo administracyjne. Pojęcia i instytucje zasadnicze, Poznań 1947, s. 104-105.

14 Sposób prowadzenia postępowania wyjaśniajacego i dyscyplinarnego w stużbie cywilnej. Poradnik, Kancelaria Prezesa Rady Ministrów, Warszawa, listopad 2011, s. 5. 
dyscyplinarną lub kwalifikowania ich przez skutki ${ }^{15}$. Podstawowe obowiązki członków korpusu służby cywilnej określone zostały w rozdziale 6 ustawy. Zaliczono do nich: przestrzeganie Konstytucji Rzeczypospolitej Polskiej i innych przepisów prawa, ochronę interesów państwa oraz praw człowieka i obywatela, racjonalne gospodarowanie środkami publicznymi, rzetelne i bezstronne, sprawne i terminowe wykonywanie powierzonych zadań, dochowywanie tajemnicy ustawowo chronionej, rozwijanie wiedzy zawodowej, godne zachowanie się w służbie oraz poza nią, a także wykonywanie poleceń bezpośrednich przełożonych.

Istotną grupę obowiązków stanowią również wytyczne związane z przestrzeganiem zasad korpusu służby cywilnej i etyki służby cywilnej ${ }^{16}$. Kolejne obowiązki członków korpusu służby cywilnej, wynikające $\mathrm{z}$ art. 78, zostały przedstawione w formie zakazów i dotyczą one:

- kierowania się interesem jednostkowym lub grupowym przy wykonywaniu obowiązków służbowych,

- publicznego manifestowania poglądów politycznych,

- uczestniczenia w strajku lub akcji protestacyjnej zakłócającej normalne funkcjonowanie urzędu,

- łączenia zatrudnienia w służbie cywilnej z mandatem radnego,

- pełnienia funkcji w związkach zawodowych (dotyczy wyższych stanowisk w służbie cywilnej),

- tworzenia partii politycznych czy uczestniczenia w nich (dotyczy urzędników mianowanych i wyższych stanowisk w służbie cywilnej),

- podejmowania dodatkowego zatrudnienia bez pisemnej zgody dyrektora generalnego urzędu i wykonywania czynności lub zajęć sprzecznych z obowiązkami wynikającymi z ustawy lub podważających zaufanie do służby cywilnej,

- podejmowania dodatkowych zajęć zarobkowych (w odniesieniu do urzędników mianowanych i wyższych stanowisk w służbie cywilnej) ${ }^{17}$.

Przywołany powyżej katalog obowiązków jest nieprecyzyjny i niedookreślony (z wyłączeniem zakazów). Taki stan rzeczy powoduje, że każdorazowo należy dokonać oceny stanu faktycznego oraz ewentualnej wagi przewinienia popełnionego przez pracownika. Trudno się jednak zgodzić się ze stwierdzeniem Piotra Zuzankiewicza, który uważa, że naruszenie zasad etycznych może służyć jedynie jako dyrektywa interpretacyjna i nie stanowi samoistnej podstawy odpowiedzialności dyscyplinarnej ${ }^{18}$. Po pierwsze - zdaniem autora - każde naruszenie aktu prawnego, niezależnie od jego rangi prawnej, stanowi podstawę do ponoszenia odpowiedzialności dyscyplinarnej. Po wtóre, wśród zasad wymienione są istotne obowiązki odnoszące się wprost do aksjomatów konstytucyjnych przynależ-

15 J. Jagielski, K. Rączka, Ustawa o stużbie..., s. 409.

16 Zob. szerzej: Zarządzenie Nr 70 Prezesa Rady Ministrów z dnia 6 października 2011 r. w sprawie wytycznych w zakresie przestrzegania zasad stuzbby cywilnej oraz w sprawie zasad etyki korpusu stużby cywilnej, M.P. 2011, nr 93, poz. 953.

17 Art. 76-80 Ustawy z dnia 21 listopada 2008 r. o stużbie cywilnej.

18 W. Drobny, M. Mazuryk, P. Zuzankiewicz, Ustawa o stużbie cywilnej. Komentarz, Warszawa 2012, s. 335. 
nych członkom korpusu służby cywilnej. Po trzecie, dla przykładu wewnętrzny regulamin pracy jest aktem niższego rzędu niż rozporządzenie, a za jego złamanie można pracownika zwolnić bez wypowiedzenia na podstawie przepisów powszechnego prawa pracy.

Dyrektor generalny urzędu nie może wszcząć postępowania dyscyplinarnego po upływie trzech miesięcy od dnia powzięcia wiadomości o naruszeniu obowiązków członka korpusu służby cywilnej ani też po upływie dwóch lat od popełnienia tego czynu $^{19}$. Karami dyscyplinarnymi stosowanymi wobec urzędników służby cywilnej są: upomnienie, nagana, pozbawienie możliwości awansowania przez okres dwóch lat na wyższy stopień służbowy, obniżenie wynagrodzenia zasadniczego nie więcej niż o 25\% - przez okres nie dłuższy niż sześć miesięcy, obniżenie stopnia służbowego służby cywilnej oraz wydalenie ze służby cywilnej.

Węższy zakres kar dyscyplinarnych dotyczy pracowników służby cywilnej. Są to: upomnienie, nagana, obniżenie wynagrodzenia zasadniczego nie więcej niż o $25 \%$ przez okres nie dłuższy niż sześć miesięcy, i wydalenie z pracy w urzędzie. Najbardziej represyjne kary związane z wydaleniem ze służby cywilnej powodują równocześnie zakaz ubiegania się o zatrudnienie w korpusie służby cywilnej przez okres pięciu lat. Dyrektor generalny urzędu posiada także prerogatywę dotyczącą wymierzania kary w postaci upomnienia pracownika na piśmie. Kara ta jest nakładana za mniejszej wagi naruszenie obowiązków członka korpusu służby cywilnej. Pracownikowi przysługuje prawo wniesienia sprzeciwu od upomnienia. W razie wniesienia sprzeciwu dyrektor generalny urzędu niezwłocznie przekazuje sprawę rzecznikowi dyscyplinarnemu. Przekazanie sprawy rzecznikowi wszczyna postępowanie wyjaśniające.

Sprawy dyscyplinarne dotyczące członków korpusu służby cywilnej rozpoznają komisje dyscyplinarne: w pierwszej instancji - komisja dyscyplinarna, $\mathrm{w}$ drugiej instancji - Wyższa Komisja Dyscyplinarna Służby Cywilnej ${ }^{20}$. Pierwszoinstancyjne komisje dyscyplinarne powoływane są przez dyrektora generalnego urzędu spośród członków korpusu służby cywilnej zatrudnionych w urzędzie. Dyrektorzy generalni urzędów mogą w drodze porozumienia powołać wspólną komisję dyscyplinarną dla kierowanych przez nich urzędów. Tryb pracy komisji dyscyplinarnej określa regulamin uchwalony przez komisję dyscyplinarną i zatwierdzony przez dyrektora generalnego urzędu. Komisja dyscyplinarna powoływana jest na okres czterech lat i musi liczyć co najmniej dziesięciu członków. Spośród członków komisji powołuje się przewodniczącego i dwóch zastępców. Do składu komisji dyscyplinarnej może zostać powołana osoba, która:

- posiada wyższe wykształcenie,

- posiada wiedzę i doświadczenie zawodowe niezbędne dla właściwego wykonywania obowiązków członka komisji dyscyplinarnej,

Art. 113 ust. 2 Ustawy z dnia 21 listopada 2008 r. o stużbie cywilnej.

20 W świetle informacji przekazanych przez dyrektorów generalnych urzędów, do końca 2012 r. komisje dyscyplinarne powołano w ponad 85\% urzędów (w 2011 r. - 84\%), w których funkcjonuje korpus służby cywilnej. W ponad $6 \%$ urzędów administracji rządowej działały samodzielne komisje. Pozostałe urzędy, w których funkcjonowały komisje, zawarły porozumienia z innymi urzędami w sprawie powołania wspólnej komisji dyscyplinarnej. Na koniec 2012 r. było zawartych 125 takich porozumień. $\mathrm{Za:} \mathrm{Sprawozdanie} \mathrm{Szefa} \mathrm{Stużby} \mathrm{Cywilnej} \mathrm{o} \mathrm{stanie} \mathrm{stużby} \mathrm{cywilnej} \mathrm{i} \mathrm{realizacji} \mathrm{zadań} \mathrm{tej} \mathrm{stużby} \mathrm{w} 2012$ roku. Zatacznik nr 8, Kancelaria Prezesa Rady Ministrów, Warszawa, marzec 2013, s. 33. 
- nie była karana za przestępstwo lub przestępstwo skarbowe,

- nie była karana dyscyplinarnie w służbie cywilnej,

- nie pełni funkcji rzecznika dyscyplinarnego ${ }^{21}$.

Rolę drugiej instancji pełni Wyższa Komisja Dyscyplinarna powoływana przez Prezesa Rady Ministrów. W skład Wyższej Komisji Dyscyplinarnej wchodzi 15 członków powoływanych przez Prezesa Rady Ministrów na okres sześciu lat, w tym 12 członków powoływanych na wniosek Szefa Służby Cywilnej spośród urzędników służby cywilnej oraz trzech członków powoływanych na wniosek dyrektora generalnego służby zagranicznej spośród członków personelu dyplomatyczno-konsularnego ${ }^{22}$. Tryb pracy Wyższej Komisji Dyscyplinarnej określa regulamin uchwalany przez komisję.

Wykonywanie zadań w komisji dyscyplinarnej przez jej członków jest traktowane na równi z wykonywaniem obowiązków pracowniczych. Ponadto członkom Wyższej Komisji Dyscyplinarnej przysługuje wynagrodzenie miesięczne ${ }^{23}$. Członkowie komisji dyscyplinarnych są niezawiśli w zakresie orzecznictwa dyscyplinarnego. Nie są też związani rozstrzygnięciami innych organów stosujących prawo, z wyjątkiem prawomocnego wyroku sądu. Komisje dyscyplinarne orzekają w składzie: trzech członków w pierwszej instancji i pięciu członków w drugiej instancji ${ }^{24}$.

Oprócz komisji dyscyplinarnej w strukturze poszczególnych urzędów funkcjonuje również rzecznik dyscyplinarny ${ }^{25}$. Powoływany on jest przez dyrektora generalnego urzędu spośród podległych mu członków korpusu służby cywilnej² ${ }^{26}$ W uzasadnionych

$21 § 3$ ust. 1 Rozporządzenia Prezesa Rady Ministrów z dnia 9 kwietnia 2009 r. w sprawie postępowania wyjaśniającego i postępowania dyscyplinarnego w stużbie cywilnej.

22 Art. 118 ust. 2 Ustawy z dnia 21 listopada 2008 r. o stużbie cywilnej. Skład Wyższej Komisji Dyscyplinarnej Służby Cywilnej, powołanej przez Prezesa Rady Ministrów 2 III 2012 r. na lata 2012-2018: Anna Borowska - Główny Urząd Statystyczny, Aleksander Dietkow - Ministerstwo Spraw Zagranicznych (zastępca przewodniczącego), Lucyna Długosz-Nowicka - Kancelaria Prezesa Rady Ministrów, Rafał Haczkiewicz - Urząd Kontroli Skarbowej w Rzeszowie, Barbara Haładyj - Ministerstwo Spraw Zagranicznych, Piotr Kobiela - Pomorski Urząd Wojewódzki w Gdańsku, Katarzyna Łupińska - Ministerstwo Finansów (zastępca przewodniczącego), Sławomir Majszyk - Ministerstwo Spraw Zagranicznych, Joanna Piekutowska - Główny Inspektorat Ochrony Środowiska, Radosław Płucisz - Ministerstwo Spraw Wewnętrznych, Katarzyna Szarkowska - Ministerstwo Transportu, Budownictwa i Gospodarki Morskiej (przewodniczący), Izabela Wereśniak-Masri - Ministerstwo Środowiska, Cezary Zaremba Ministerstwo Administracji i Cyfryzacji oraz Anna Żółkowska - Ministerstwo Gospodarki.

23 Rozporzadzenie Prezesa Rady Ministrów z dnia 9 kwietnia 2009 r. w sprawie wynagrodzenia cztonków Wyższej Komisji Dyscyplinarnej Stużby Cywilnej, komisji dyscyplinarnych oraz rzeczników dyscyplinarnych i ich zastępców, Dz.U. 2009, nr 60, poz. 492.

24 Wyjątek stanowi orzeczenie o wydaleniu ze służby cywilnej. Wówczas komisja orzeka w składzie pięcioosobowym, w tym przewodniczący składu posiadający wykształcenie prawnicze.

25 W 2012 r. w urzędach administracji rządowej, w których funkcjonuje korpus służby cywilnej, działato 933 rzeczników dyscyplinarnych. Wspólny rzecznik dyscyplinarny funkcjonował w 444 urzędach, natomiast zastępca rzecznika lub wspólnego rzecznika dyscyplinarnego działał w 841 urzędach. Za: Sprawozdanie Szefa Stużby Cywilnej o stanie stużby cywilnej i realizacji zadań tej stużby w 2012 roku. Zatacznik nr 8, Warszawa, marzec 2013, s. 33.

26 Rzecznika dyscyplinarnego do spraw dyscyplinarnych osób zajmujących stanowiska dyrektorów generalnych urzędów powołuje Szef Służby Cywilnej spośród członków korpusu służby cywilnej, art. 124 ust. 2 Ustawy z dnia 21 listopada 2008 r. o stużbie cywilnej. 
przypadkach może zostać powołany także zastępca rzecznika dyscyplinarnego. Rzecznik dyscyplinarny powoływany jest spośród osób, które: posiadają wyższe wykształcenie, posiadają wiedzę i doświadczenie zawodowe niezbędne dla właściwego wykonywania obowiązków rzecznika dyscyplinarnego, nie były karane za przestępstwo lub przestępstwo skarbowe oraz nie były karane dyscyplinarnie w służbie cywilnej ${ }^{27}$.

Rzecznik dyscyplinarny wszczyna postępowanie wyjaśniające na polecenie dyrektora generalnego urzędu. O wszczęciu postępowania rzecznik zawiadamia osobę, której ono dotyczy. Polecenie wydane przez dyrektora generalnego ma dla rzecznika dyscyplinarnego charakter wiążący i skutkuje koniecznością podjęcia przez niego czynności właściwych dla tego etapu ustalania odpowiedzialności dyscyplinarnej ${ }^{28}$. W ustawie nie wprowadzono instytucji odmowy wszczęcia postępowania wyjaśniającego przez rzecznika. Należy więc przyjąć, że w tym zakresie jedynym możliwym trybem kwestionowania przez rzecznika polecenia dyrektora generalnego jest ogólny mechanizm zawarty w art. 77 ust. 2 ustawy, a dotyczący prawnych przesłanek kwestionowania polecenia przełożonego ${ }^{29}$.

Otrzymanie polecenia wszczęcia postępowania wyjaśniającego skutkuje przekazaniem komisji dyscyplinarnej wniosku o wszczęcie postępowania dyscyplinarnego albo za zgodą dyrektora generalnego urzędu - umorzeniem postępowania wyjaśniającego. Przekazanie wniosku do komisji wszczyna postępowanie dyscyplinarne. W trakcie postępowania dyscyplinarnego obwiniony pracownik ma prawo korzystania z pomocy wybranego przez siebie obrońcy ${ }^{30}$. Komisja wydaje orzeczenie jest po przeprowadzeniu rozprawy, w toku której wysłuchuje ona rzecznika dyscyplinarnego i obwinionego oraz jego obrońcy, jeżeli został ustanowiony, a także po rozpatrzeniu innych dowodów mających znaczenie w sprawie ${ }^{31}$. Co do zasady rozprawy dyscyplinarne są jawne. Wyłączenie jawności może nastąpić wyłącznie w uzasadnionych przypadkach, jednak nie powoduje to utajnienia samego wyniku postępowania. Od orzeczenia komisji orzekającej w pierwszej instancji przysługuje odwołanie do Wyższej Komisji Dyscyplinarnej, które powinno nastąpić w ciągu 14 dni od dnia doręczenia orzeczenia komisji pierwszej instancji. Od orzeczeń Wyższej Komisji Dyscyplinarnej stronom oraz Szefowi Służby Cywilnej przysługuje odwołanie do sądu apelacyjnego - sądu pracy i ubezpieczeń społecznych, właściwego ze względu na miejsce zamieszkania obwinionego.

Jak stwierdził w uzasadnieniu wyroku Sąd Apelacyjny w Szczecinie:

[...] przypisanie odpowiedzialności dyscyplinarnej o charakterze deliktowym nie może opierać się na uprawdopodobnieniu, ale musi wynikać $z$ wykazanych w sposób niezbity i nie budzacy jakichkolwiek wątpliwości faktów, które oczywiście dowodzą o naruszeniu

$27 \$ 6$ ust. 1 Rozporzadzenia Prezesa Rady Ministrów z dnia 9 kwietnia 2009 r. w sprawie postępowania wyjaśniającego i postępowania dyscyplinarnego w stużbie cywilnej.

Zob. szerzej: M. Gubała, Ł. Paszka, O niektórych..., s. 58.

29 Tamże.

30 Zob. szerzej: art. 126 ust. 2 Ustawy z dnia 21 listopada 2008 r. o stużbie cywilnej. W przypadku, gdy rzecznik dyscyplinarny wniósł o orzeczenie kary wydalenia ze służby cywilnej albo kary wydalenia z pracy w urzędzie, a obwiniony nie ma obrońcy z wyboru, przewodniczący składu orzekającego wyznacza obrońcę spośród członków korpusu służby cywilnej. 
obowiazków cztonka korpusu. Wymaga to zawsze dowodów nie budzacych watpliwości, spójnych i precyzyjnych, a dokonujac ich oceny, nie można abstrahować od catoksztattu okoliczności, w tym sposobu organizacji pracy, relacji pomiędzy pracownikami, występujacych $w$ zaktadzie pracy zależności, $w$ tym osobistych sympatii i antypatii, a także pewnych cech osobowościowych uczestników konfliktu i wynikających z tego emocji ${ }^{32}$.

Orzeczenie wydane w efekcie postępowania dyscyplinarnego dołącza się do akt osobowych członka korpusu służby cywilnej ${ }^{33}$. Kary dyscyplinarne określone w ustawie ulegają zatarciu, a odpis orzeczenia dołączony do akt osobowych podlega zniszczeniu po upływie trzech lat od dnia doręczenia prawomocnego orzeczenia o ukaraniu. $\mathrm{Na}$ wniosek ukaranego zatarcie może nastąpić po upływie dwóch lat.

Liczbę przeprowadzonych postępowań wyjaśniających i dyscyplinarnych oraz orzeczonych kar dyscyplinarnych prezentują poniższe zestawienia.

W 2014 r. w urzędach administracji rządowej, w których funkcjonuje korpus służby cywilnej, wszczęto 519 postępowań wyjaśniających (w 2013 r. - 538) oraz 262 postępowania dyscyplinarne ( $276 \mathrm{w} 2013$ r.). Umorzono 216 postępowań wyjaśniających ${ }^{34}$. W 2014 r. uprawomocnity się 173 kary dyscyplinarne, w tym jedna najbardziej represyjna kara polegająca na wydaleniu ze służby cywilnej. Ponad $40 \%$ wszystkich wszczętych w 2014 r. postępowań wyjaśniających stanowiły postępowania w związku z naruszeniem obowiązków stanowiących jednocześnie naruszenie zasad służby cywilnej lub zasad etyki korpusu służby. Największa część tych postępowań, podobnie jak w latach ubiegłych, dotyczyła zasady godnego zachowania - ok. 22\%, oraz zasady rzetelności ok. $22 \%$ postępowań ${ }^{35}$.

Niestety brak szczegółowych informacji na temat konkretnych typów zachowań i rodzajów przewinień będących podstawą do wszczęcia postępowania wyjaśniającego. Można jednak przyjąć, że zachowania lub przewinienia miały związek z naruszeniem przepisów zarządzenia etycznego wynikających $\mathrm{z}$ ich literalnego brzmienia. W świetle przywołanego aktu prawnego zasada godnego zachowania nakłada na członków korpusu służby cywilnej obowiązek wykonywania pracy z poszanowaniem reguł współżycia społecznego i kultury osobistej oraz poszanowania godności innych osób, także podwładnych, kolegów i przełożonych ${ }^{36}$. Dodatkowo wymaga od adresatów życzliwego traktowania obywateli i zapobiegania powstawaniu konfliktów, m.in. w relacjach z obywatelami ${ }^{37}$.

32 Wyrok Sądu Apelacyjnego w Szczecinie z dnia 11 grudnia 2012 r., sygn. III ZPo 5/12.

33 W przypadku wydalenia ze służby cywilnej zatarcie kary oraz zniszczenie odpisu orzeczenia następuje po upływie trzech lat od dnia upływu okresu. Kara upomnienia na piśmie ulega zatarciu po upływie roku od dnia uprawomocnienia.

34 Sprawozdanie Szefa Stużby Cywilnej o stanie stużby cywilnej i realizacji zadań tej stużby w 2014 roku. Zatączik nr 9, Kancelaria Prezesa Rady Ministrów, Warszawa, marzec 2015, s. 27.

35 Tamże.

36 Zarządzenie $\mathrm{Nr} 70, \$ 14$.

37 D. Długosz, W. Zawadzki, Etyczny drogowskaz urzędników. Zasady etyki w praktyce administracji, „Przegląd Służby Cywilnej” 2011, wydanie specjalne nr 1, s. 10-11; A. Melezini, Wprowadzenie kodeksu etyki stuzby cywilnej, [w:] Prawne instrumenty zapobiegania i zwalczania korupcji przez kontrole skarbowa, Warszawa 2012, s. 207-208. 


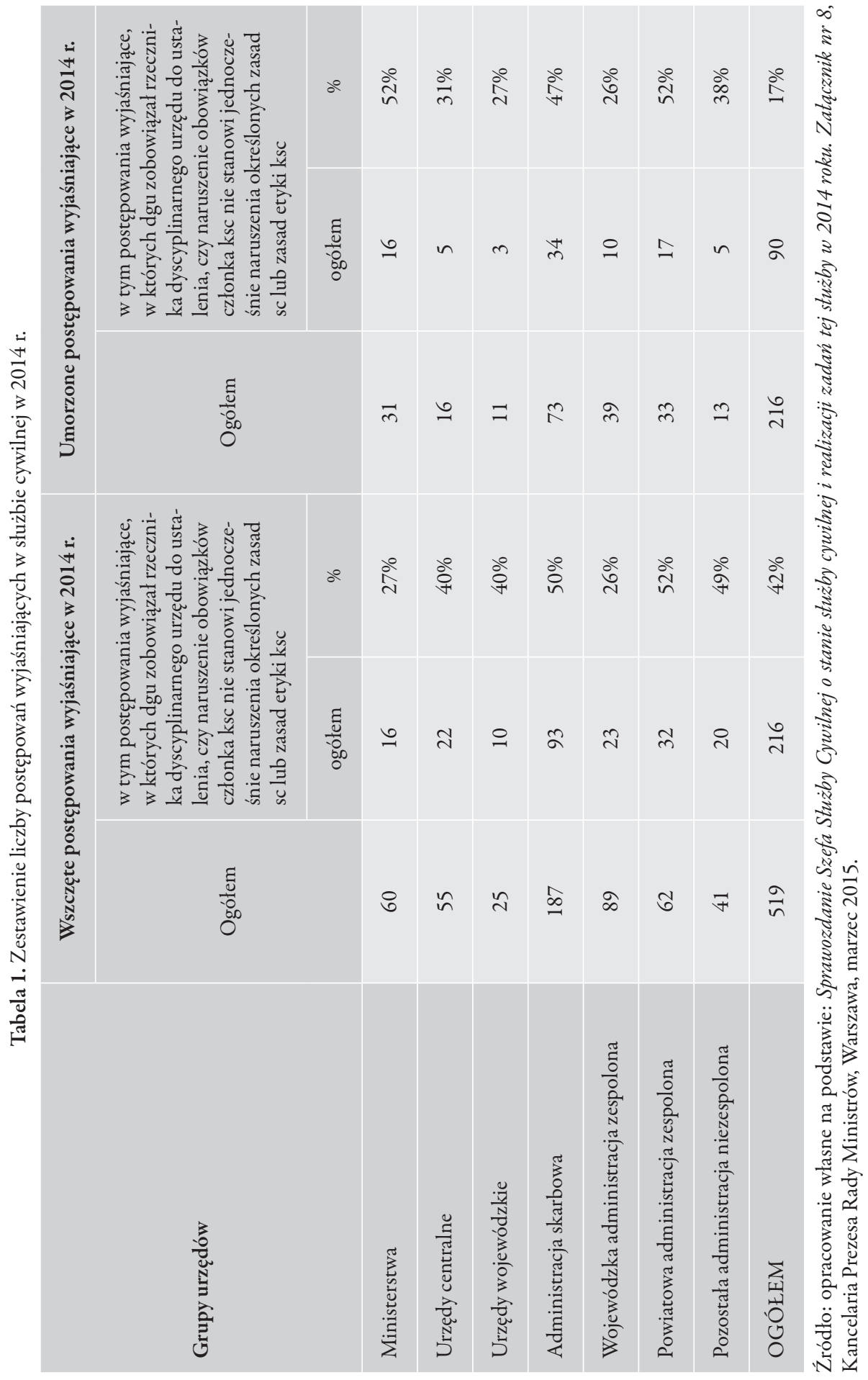




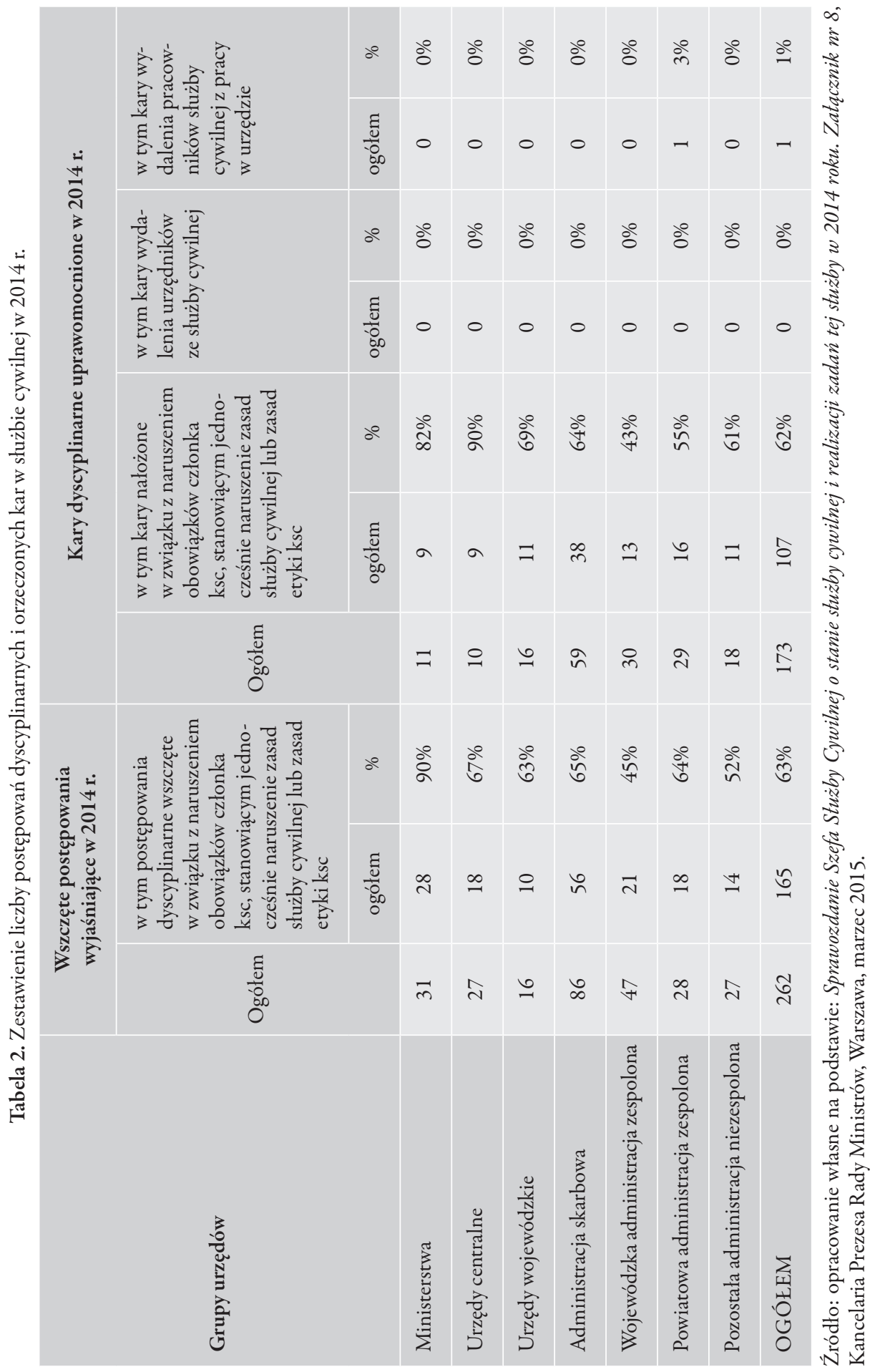


Warto jednak zauważyć, że w doktrynie pojęcie godnego zachowania nie jest jednoznacznie zdefiniowane. Można domniemywać, że ustawodawca, posługując się tym pojęciem, miał na myśli wszelkie zachowania członka korpusu służby cywilnej, które negatywnie wpływają na wizerunek służby cywilnej, jej postrzeganie przez społeczeństwo oraz otoczenie instytucjonalne ${ }^{38}$. W służbie cywilnej zasada godnego zachowania nie odnosi się wyłącznie do sytuacji zawodowych. Obowiązuje urzędników również na płaszczyźnie życia prywatnego, zwłaszcza w kontekście unikania niepożądanych zachowań mających negatywny wpływ na wizerunek państwa, służby cywilnej i urzędu ${ }^{39}$.

Druga z najczęściej naruszanych zasad odnosi się do rzetelności. W tym przypadku ustawodawca założył, że rzetelność członków korpusu służby cywilnej polega na sumiennym i rozważnym realizowaniu powierzonych zadań, dotrzymywaniu zobowiązań (zgodnie z przepisami prawa), a także na twórczym podejmowaniu zadań i aktywnym realizowaniu obowiązków zgodnie z najlepszą wolą i w interesie społecznym, co oznacza coś więcej niż tylko ścisłe przestrzeganie przepisów ${ }^{40}$.

Zasadne w świetle przywołanych powyżej danych wydaje się również wyjaśnienie, dlaczego w niektórych urzędach spraw dyscyplinarnych jest więcej, a w innych mniej. Zdaniem autora niezbędne jest wobec tego odniesienie się do ogólnej liczby wszczętych postępowań wyjaśniających $\mathrm{w}$ stosunku do liczby pracowników zatrudnionych w poszczególnych rodzajach urzędów. Uzyskane wyniki pokazują (tab. 3), że co do zasady procentowy udział wszczętych postępowań dyscyplinarnych jest zbliżony we wszystkich typach urzędów. Różnice w liczbach bezwzględnych wynikają z różnego poziomu zatrudnienia. Nie można wobec tego sformułować tezy, że w wybranych typach urzędów częściej dochodzi do naruszeń przepisów prawa powodujących konieczność wszczęcia postępowania wyjaśniającego, a w konsekwencji postępowania dyscyplinarnego. Liczba wszczętych postępowań w stosunku do poziomu zatrudnienia pozwala jednak na stwierdzenie, że skala naruszeń obowiązków przez członków korpusu służby cywilnej powodujących konieczność podjęcia działań dyscyplinarnych jest marginalna. W przypadku każdej z grup mamy bowiem do czynienia z procentowym udziałem na poziomie $0,5 \%$. Poziom ten $\mathrm{z}$ dużym prawdopodobieństwem nie odbiega znacząco od innych grup zawodowych.

Dla pełniejszego zobrazowania omawianego zagadnienia warto w tym miejscu przywołać również dane historyczne prezentujące dynamikę liczby postępowań wyjaśniających na przestrzeni lat 2009-2014. Jak wynika z poniższych danych, rozpiętość

38 K. Mroczka, Wptyw polityki..., s. 256.

Zasada ta - jako jedyna z omawianego kodeksu - była dotychczas przedmiotem orzecznictwa sądów powszechnych. Sąd Apelacyjny w Rzeszowie podkreślit, że pracownik stużby cywilnej może wyrażać opinie o swoim zaktadzie pracy, czy też przetożonym, winien to jednak czynić w sposób stosowny. Niedopuszczalne jest wyrażanie dezaprobaty dla kierownika zaktadu pracy w sposób agresywny, w obraźliwych stowach. Takie zachowanie stanowi naruszenie obowiazków cztonka korpusu stużby cywilnej i winno skutkować, co najmniej zastosowaniem jednej z kar dyscyplinarnych przewidzianych ustawą $z 2008$ roku o stużbie cywilnej. Wyrok Sądu Apelacyjnego w Rzeszowie z dnia 8 listopada 2012 r., sygn. III APo 7/12. 
liczbowa wszczętych postępowań jest znacząca w liczbach bezwzględnych. Najwięcej postępowań wyjaśniających wszczęto w 2012 r. (630), najmniej zaś w roku 2010 (441). Niezbędne jest również pokreślenie, że liczba postępowań wyjaśniających w ciągu ostatnich lat znacząco spadła. W latach 2012-2014 odnotowano spadek o ponad 100 spraw.

Tabela 3. Stosunek liczby wszczętych postępowań wyjaśniających do liczby zatrudnionych członków korpusu służby cywilnej w $2014 \mathrm{r}$.

\begin{tabular}{|l|c|c|c|}
\hline Grupy urzędów & $\begin{array}{c}\text { Liczba } \\
\text { etatów }\end{array}$ & $\begin{array}{c}\text { Liczba } \\
\text { postępowań }\end{array}$ & $\begin{array}{c}\text { Stosunek } \\
\text { procentowy }\end{array}$ \\
\hline Ministerstwa & 12352 & 60 & $0,48 \%$ \\
\hline Urzędy centralne & 11085 & 55 & $0,49 \%$ \\
\hline Urzędy wojewódzkie & 8733 & 25 & $0,28 \%$ \\
\hline Administracja skarbowa & 46685 & 187 & $0,40 \%$ \\
\hline Wojewódzka administracja zespolona & 14883 & 89 & $0,59 \%$ \\
\hline Powiatowa administracja zespolona & 8577 & 62 & $0,72 \%$ \\
\hline Pozostała administracja niezespolona & 16844 & 41 & $0,24 \%$ \\
\hline
\end{tabular}

Źródło: opracowanie własne na podstawie: Sprawozdanie Szefa Stużby Cywilnej o stanie stużby cywilnej i realizacji zadań tej stużby w 2014 roku. Zatączniki nr 1 i 8, Kancelaria Prezesa Rady Ministrów, Warszawa, marzec 2015 .

Tabela 4. Zestawienie postępowań wyjaśniających w służbie cywilnej w latach 2009-2014

\begin{tabular}{|l|c|c|c|c|c|c|}
\hline Liczba wszczętych & 2009 & 2010 & 2011 & 2012 & 2013 & 2014 \\
\hline postępowań wyjaśniających & 478 & 441 & 591 & 630 & 538 & 519 \\
\hline
\end{tabular}

Źródło: opracowanie własne na podstawie: Sprawozdań Szefa Stużby Cywilnej o stanie stużby cywilnej i realizacji zadań tej stużby w latach 2009-2014, Kancelaria Prezesa Rady Ministrów, Warszawa 2010-2015.

Zdaniem autora ograniczenie liczby postępowań wyjaśniających w ciągu ostatnich lat wynikało m.in. z podejmowanych przez Szefa Służby Cywilnej działań na rzecz świadomości etycznej członków korpusu służby cywilnej. Przykładem takiej aktywności były m.in. dodatki tematyczne do branżowego periodyku „Przegląd Służby Cywilnej” oraz szkolenia z zakresu etyki i zarządzania etycznego. Wynika to również z większej świadomości członków korpusu służby cywilnej w związku z podejmowanymi przez pracodawców i Szefa Służby Cywilnej działaniami promocyjnymi i informacyjnymi na temat etyki i zarządzania etycznego. Wzrasta również poziom kompetencji pracowników realizujących zadania publiczne.

W opinii autora nie bez znaczenia jest również sytuacja na rynku pracy, która wpływa na zachowania pracowników. Doświadczenia własne autora związane z zatrudnieniem na stanowiskach menedżerskich odpowiedzialnych za zarządzanie zasobami ludzkimi potwierdzają tę tezę. Pracownicy, obawiając się utraty pracy, prezentują mniejszą skłonność do podejmowania działań nieetycznych i sprzecznych z przepisami prawa. 


\section{ODPOWIEDZIALNOŚĆ KARNA FUNKCJONARIUSZY PUBLICZNYCH}

Drugi rodzaj analizowanej odpowiedzialności odnosi się do sfery prawa karnego. Funkcjonariusze publiczni mogą popełnić większość przestępstw określonych w Kodeksie karnym ${ }^{41}$ czy innych ustawach precyzujących odpowiedzialność karną. Jednak, ze względu na sprawowanie i wykonywanie funkcji publicznej i władztwa administracyjnego, pewne typy przestępstw mogą popełnić wyłącznie przedstawiciele tej grupy zawodowej. Tradycyjnie przestępstwa te określane są mianem „przestępstw urzędniczych". Doktryna i judykatura do kategorii tej zalicza: nadużycie władzy, korupcję i łapownictwo, umyślne niedopełnienie obowiązków służbowych, wykonanie polecenia prowadzącego do popełnienia przestępstwa, nieprzestrzeganie przepisów dotyczących ochrony informacji niejawnych, ochrony danych osobowych, poświadczenie nieprawdy czy nieprawidłowości przy zamówieniach publicznych ${ }^{42}$.

Definicja funkcjonariusza publicznego określona została w art. $115 \$ 13$ Kodeksu karnego. Stanowi on, że funkcjonariuszem publicznym jest m.in. Prezydent Rzeczypospolitej Polskiej, poseł, senator, radny, sędzia, prokurator oraz osoby będące pracownikami administracji rządowej, innych organów państwowych lub samorządu terytorialnego, chyba że pełnią wyłącznie czynności usługowe, a także inne osoby w zakresie, w którym uprawnione są do wydawania decyzji administracyjnych. Do ostatniego zbioru zaliczamy niewątpliwie członków korpusu służby cywilnej. Jak wynika z powyższego przepisu, definicja funkcjonariuszy publicznych jest szeroka i wykracza poza zakres pracowników administracji publicznej.

Odpowiedzialność karna w ujęciu europejskiego prawa karnego jest odpowiedzialnością sprawczą indywidualną, a zatem przesłanką decydującą jest wina sprawcy oraz oczywiście popełnienie czynu wyraźnie zakazanego przez ustawę ${ }^{43}$. Jak podkreśla Mirosław Wincenciak, sankcje karne mają być traktowane jako ultima ratio, a nie prima ratio w zakresie regulowania stosunków społecznych, gdyż sankcja karna jest w swojej istocie środkiem najbardziej dolegliwym z możliwych ${ }^{44}$. Na gruncie polskiego prawa konstytucyjnego odpowiedzialność karna została określona w art. 42 ust. 1 Konstytucji. Stanowi on, że odpowiedzialności karnej podlega ten tylko, kto dopuścit się czynu zabronionego pod groźbą kary przez ustawe obowiazująca w czasie jego popetnienia. Zasada ta nie stoi na przeszkodzie ukaraniu za czyn, który w czasie jego popetnienia stanowit przestęstwo $w$ myśl prawa międzynarodowego ${ }^{45}$.

Zakres odpowiedzialności karnej funkcjonariuszy publicznych nie został określony w jednej części Kodeksu karnego. Przepisów regulujących przestępstwa urzędnicze

$41 \quad$ Ustawa z dnia 6 czerwca 1997 r. Kodeks karny, Dz.U. 1997, nr 88, poz. 553, z późn. zm.

42 E. Ura, Odpowiedzialność prawna stużby publicznej w administracji rządowej i samorzadu terytorialnego, [w:] Stużba publiczna. Stan obecny i oczekiwania, red. M. Stec, S. Płażek, Warszawa 2013, s. 297 i nast.

43 P. Suwaj, Konflikt interesów w administracji publicznej, Warszawa 2009, s. 184.

44 M. Wincenciak, Sankcje w prawie administracyjnym i procedura ich wymierzania, Warszawa 2008, s. 103, za: P. Suwaj, Konflikt..., s. 184.

45 Art. 42 ust. 1 Konstytucji Rzeczypospolitej Polskiej, 2 IV 1997, Dz.U. 1997, nr 78, poz. 483. 
należy szukać w kilku przepisach kodeksowych oraz innych uregulowaniach prawnych, np. ustawach o dostępie do informacji publicznej, związkach zawodowych, finansach publicznych czy prawie zamówień publicznych. $Z$ uwagi na charakter niniejszego artykułu zasygnalizowane tu zostaną wyłącznie podstawowe kwestie związane z odpowiedzialnością karną członków korpusu służby cywilnej jako funkcjonariuszy publicznych.

Podstawowymi przestępstwami urzędniczymi są czyny określone w art. 228 i 229 Kodeku karnego, czyli sprzedajność urzędnicza i przekupstwo ${ }^{46}$. Sprzedajność urzędnicza polega na przyjęciu korzyści majątkowej lub osobistej albo jej obietnicy w związku z pełnieniem funkcji publicznej. Zgodnie z poglądem Sądu Najwyższego nieistotne z punktu widzenia odpowiedzialności karnej jest określenie momentu przyjęcia korzyści. Można ją przyjąć zarówno przed, jak i po dokonaniu czynności służbowej, natomiast w wypadku uzależnienia wykonania czynności od wręczenia korzyści majątkowej przyjęcie korzyści jest warunkiem podjęcia czynności ${ }^{47}$. Przekupstwo, określone w art. 229, polega na umyślnym udzieleniu korzyści majątkowej lub osobistej albo jej obietnicy osobie pełniącej funkcję publiczną. Z udzieleniem korzyści majątkowej mamy do czynienia w przypadku fizycznego wręczenia, natomiast obietnica udzielenia korzyści może być wyrażona w każdy sposób, a więc i gestem, bo przepisy nie ograniczają znamienia czasownikowego ani co do sposobu, ani co do formy uzewnętrznienia zamiaru uczynienia obietnicy ${ }^{48}$.

Przyjęte uregulowania mają na celu skuteczne zwalczanie korupcji i przekupstwa poprzez wprowadzenie katalogu sankcji karnych oraz pozbawienie sprawców korzyści majątkowych wynikających z przestępstw. Uregulowania te mają spełniać również funkcję profilaktyczną. Korupcja w sensie prawnym jest przestępstwem ściganym z urzędu i podlega karze. Kary dotyczą zarówno osoby oferującej, jak i osoby przyjmującej korzyść. Do sankcji należy zaliczyć: karę pozbawienia wolności i ograniczenia wolności, karę grzywny oraz środki karne w postaci: odpowiedzialności dyscyplinarnej, zakazu zajmowania określonego stanowiska, wykonywania zawodu (np. lekarza, nauczyciela), przepadku przedmiotów przestępstwa, przepadku korzyści, podania wyroku do publicznej wiadomości lub świadczenia pieniężnego na określony cel społeczny ${ }^{49}$.

Kolejny rodzaj odpowiedzialności karnej wiąże się z przestępstwem tzw. płatnej protekcji ${ }^{50}$. Artykuł 230 Kodeksu karnego stanowi, że kto, powotując się na wptywy winstytu-

46 Zob. szerzej: J. Lachowski, Przestępstwa przeciwko dziatalności instytucji państwowych oraz samorzadu terytorialnego, [w:] Kodeks karny. Czesśćszczególna, t. 2: Komentarz art. 222-316, red. M. Królikowski, R. Zawłocki, Warszawa 2013, s. 93 i nast.

47 Wyrok Sądu Najwyższego - Izba Wojskowa z dnia 8 listopada 1974 r., sygn. Rw 522/74, „Orzecznictwo Sądu Najwyższego - Wydawnictwo Prokuratury Generalnej” 1975, z. 2, poz. 20.

48 Wyrok Sądu Najwyższego - Izba Karna z dnia 5 listopada 1997 r., sygn. V KKN 105/97, „Orzecznictwo Izby Karnej i Wojskowej Sądu Najwyższego” 1998, z. 1-2, poz. 7; zob. także: J. Satko, Glosa do wyroku SN z dnia 5 listopada 1997 r., VKKN 105/97. Teza nr 1, 14800/1, „Orzecznictwo Sądów Polskich" 1998, z. 6, poz. 117.

49 Poradnik antykorupcyjny dla urzędników, Centralne Biuro Antykorupcyjne, Warszawa 2011, s. 31. Tamże zamieszczono praktyczne przykłady zachowań kwalifikowanych jako zachowania korupcyjne na gruncie przepisów kodeksu karnego.

50 Zob. szerzej: J. Lachowski, Przestępstwa przeciwko..., s. 133 i nast. 
cjipaństwowej, samorządowej, organizacji międzynarodowej albo krajowej lub w zagranicznej jednostce organizacyjnej dysponującej środkami publicznymi albo wywotujac przekonanie innej osoby lub utwierdzajac ją w przekonaniu o istnieniu takich wptywów, podejmuje sie pośrednictwa w zatatwieniu sprawy w zamian za korzyść majątkowa lub osobista albo jej obietnice, podlega karze pozbawienia wolności od 6 miesięcy do lat 8. Omawiany rodzaj jest przestępstwem formalnym, dokonywanym z chwilą podjęcia się przez sprawcę pośrednictwa w załatwieniu sprawy w zamian za korzyść majątkową lub jej obietnicę. Dla istoty tego przestępstwa nie jest konieczne stwierdzenie udziału funkcjonariusza publicznego. Faktyczne osiągnięcie przez sprawcę lub osobę trzecią takiej korzyści, jak również to, czy i w jaki sposób sprawca realizuje pośrednictwo w załatwieniu sprawy oraz czy działa w ogóle w zamiarze takiego pośredniczenia, nie należą do znamion tego przestępstwa ${ }^{51}$.

W art. 230a określono szczególny rodzaj płatnej protekcji związanej z handlem wpływami w instytucjach publicznych. Przestępstwo to polega na udzieleniu lub obietnicy udzielenia pośrednikowi korzyści majątkowej lub osobistej w zamian za pośrednictwo w załatwieniu sprawy w instytucji państwowej, samorządowej, organizacji międzynarodowej albo krajowej lub w zagranicznej jednostce organizacyjnej dysponującej środkami publicznymi, a samo działanie sprawcy ma skłonić pośrednika do bezprawnego wywarcia wpływu na decyzję osoby pełniącej funkcję publiczną ${ }^{52}$.

Odpowiedzialność karną członkowie korpusu służby cywilnej ponoszą również za przestępstwa związane z nadużyciem funkcji, przekroczeniem uprawnień i niedopełnieniem obowiązków oraz działaniem na szkodę interesu publicznego lub prywatnego. Jak podkreślił Trybunał Konstytucyjny, jest to klasyczne, najbardziej charakterystyczne przestępstwo funkcjonariuszy, które godzi w autorytet oraz zaufanie spoteczne do reprezentowanych przez nich wtadz i instytucji, a także w konkretne interesy i dobra spoteczne lub jednostkowe, zagrożone lub naruszone przestępnym zachowaniem ${ }^{53}$. Z przekroczeniem uprawnień mamy do czynienia np. w sytuacjach, w których urzędnik podejmuje czynności i decyzje wykraczające poza jego uprawnienia służbowe (np. podpisywanie decyzji zastrzeżonych do wyłącznej kompetencji dyrektora generalnego urzędu lub kierownika jednostki czy wydawanie decyzji administracyjnych bez odpowiedniego upoważnienia). $\mathrm{Z}$ niedopełnieniem obowiązków mamy do czynienia w sytuacji zaniechania wykonania obowiązków, nienależytego wykonania sprzecznego z istotą lub charakterem danego obowiązku prawnego. Warto jednak dodać, że zgodnie z przyjętą linią orzeczniczą samo zaniechanie działania, przekroczenie uprawnień przez funkcjonariusza publicznego czy niedopełnienie obowiązków nie stanowi przestępstwa, bowiem przestępstwo to musi być zawinione umyślnie, co oznacza, że funkcjonariusz publiczny

51 Zob. szerzej: Wyrok Sądu Najwyższego z dnia 2 marca 1972 r., sygn. II KR 4/71, „Orzecznictwo Sądu Najwyższego - Wydawnictwo Prokuratury Generalnej” 1972, z. 2, poz. 156; Wyrok Sądu Najwyższego z dnia z 17 września 1974 r., sygn. IV KR 191/74, „Orzecznictwo Sądu Najwyższego - Wydawnictwo Prokuratury Generalnej” 1975, nr 2 poz. 22; Wyrok Sądu Najwyższego z 29 lutego 1984 r., sygn. RW 53/84, „Orzecznictwo Sądu Najwyższego - Izba Karna i Wojskowa” 1984, z. 9-10, poz. 94.

Poradnik antykorupcyjny..., s. 20.

53 Wyrok Trybunału Konstytucyjnego z dnia 9 czerwca 2010 r., sygn. SK 52/08, Dz.U. 2010, nr 117, poz. 790, „Orzecznictwo Trybunału Konstytucyjnego Zbiór Urzędowy”, nr 5/A/2010. 
musi obejmować swoim zamiarem (bezpośrednim lub ewentualnym) zarówno przekroczenie uprawnień lub niedopełnienie obowiązków (w wyniku działania lub zaniechania), jak i „działanie” na szkodę interesu publicznego lub prywatnego charakteryzujące to przekroczenie uprawnień lub niedopełnienie obowiązków ${ }^{54}$.

W roku 2010 do Kodeksu karnego wprowadzono dodatkową regulację związaną z ochroną prawną funkcjonariuszy publicznych ${ }^{55}$. Celem ustawodawcy było wzmocnienie prawnej ochrony tych kategorii funkcjonariuszy publicznych, którzy z racji charakteru pełnionych obowiązków są w największym stopniu narażeni na niebezpieczeństwo osobiste, a których skuteczne działanie jest najistotniejsze w płaszczyźnie zapobiegania i zwalczania przestępczości oraz budowania poczucia bezpieczeństwa publicznego ${ }^{56}$.

W'śród przestępstw urzędniczych zagrożonych sankcjami karnymi możemy również wymienić przestępstwa związane ze złamaniem tajemnicy służbowej, poświadczaniem nieprawdy, fałszerstwem i fałszerstwem intelektualnym. Ze złamaniem tajemnicy służbowej mamy do czynienia w sytuacjach ujawniania lub wykorzystywania informacji pozyskanych w związku z pełnioną funkcją lub zajmowanym stanowiskiem. Przestępstwo to może polegać również na naruszeniu tajemnicy państwowej, zawodowej lub służbowej. Szczegółowo kwestie związane z ochroną informacji niejawnych zostały uregulowane w drodze ustawy ${ }^{57}$. Fałszowanie dokumentów polega na podrabianiu lub przerabianiu dokumentu w celu użycia go jako autentycznego. Szczególnym rodzajem fałszerstwa jest fałszerstwo intelektualne. Polega ono na wystawianiu dokumentu, w którym celowo poświadcza się nieprawdę co do okoliczności mającej znaczenie prawne (np. zaświadczenie o zarobkach pracownika).

Wymienione powyżej przestępstwa karne nie stanowią katalogu pełnego i zamkniętego, są jedynie egzemplifikacją mającą na celu zaprezentowanie szerokiego katalogu sankcji związanych z zatrudnieniem w służbie cywilnej, a także - szerzej - w administracji publicznej.

\section{ODPOWIEDZIALNOŚĆ W ZAKRESIE FINANSÓW PUBLICZNYCH}

Odpowiedzialność za naruszenie dyscypliny finansów publicznych reguluje w polskim systemie prawnym Ustawa z dnia 17 grudnia 2004 r. o odpowiedzialności za naruszenie dyscypliny finansów publicznych ${ }^{58}$. Jest ona uzupełnieniem ustawy o finansach

54 Postanowienie Sądu Najwyższego z dnia 25 lutego 2003 r., sygn. WK 3/03, „Orzecznictwo Sądu Najwyższego - Izba Karna i Wojskowa” 2003, z. 5-6, poz. 53.

55 Ustawa z dnia 26 listopada 2011 r. o zmianie ustawy - Kodeks karny oraz ustawy o Policji, Dz.U. 2011, nr 240, poz. 1602.

56 M. Jachimowicz, Charakterystyka ustawy z dnia 26 listopada 2010 r. o zmianie ustawy - Kodeks karny oraz ustawy o Policji, [online] http://pila.szkolapolicji.gov.pl/joomla/images/Zamowienia/Kwartalnik/Nr6-7/kk.pdf, 20 IV 2014.

57 Ustawa z dnia 5 sierpnia 2010 r. o ochronie informacji niejawnych, Dz.U. 2010, nr 182, poz. 1228.

58 Ustawa z dnia 17 grudnia 2004 r. o odpowiedzialności za naruszenie dyscypliny finansów publicznych, Dz.U. 2013, nr 168. 
publicznych ${ }^{59}$, która - podobnie jak poprzednie przepisy - stanowi swoisty kodeks finansów publicznych ${ }^{60}$. Wszystkie jednostki zaliczane do sektora finansów publicznych podlegają przepisom wyżej wymienionych ustaw, a osoby dysponujące środkami publicznymi mogą być pociągnięte do odpowiedzialności z tytułu naruszenia dyscypliny finansów publicznych. W ustawie o finansach publicznych brak legalnej definicji dyscypliny finansów publicznych, jednak w kontekście, w jakim używane jest to pojęcie, należy przyjąć, że dyscyplina finansów publicznych odnosi się do obowiązku przestrzegania zasad gospodarowania środkami publicznymi. Zasady te ograniczone zostaty do dwóch zasadniczych: efektywnego gospodarowania środkami publicznymi i ścistego respektowania procedur $i$ zakresu uprawnień do dysponowania środkami publicznymi ${ }^{61}$. Jak dodaje Ludmiła Lipiec-Warzecha, w przypadku naruszenia dyscypliny finansów publicznych chodzi nie tylko o prawo stricte finansowe, ale także o normy objęte prawem zamówień publicznych czy ustawą o rachunkowości ${ }^{62}$.

W wyroku Naczelnego Sądu Administracyjnego możemy odnaleźć cel wprowadzenia takiej konstrukcji do systemu prawnego. Sąd ten stwierdzit, że odpowiedzialność za naruszenie dyscypliny finansów publicznych (wcześniej dyscypliny budżetowej) ma stużyć przede wszystkim egzekwowaniu od dysponujacych środkami publicznymi prawidtowego wykonywania planów finansowych jednostek dziatajacych w oparciu o środki publiczne, nie zaś ocenie, czy plany te byty adekwatne do potrzeb danych jednostek ${ }^{63}$.

Krąg podmiotów, które odpowiadają za naruszenie dyscypliny finansów publicznych, został określony w art. 4. Zaliczono do nich m.in.:

- osoby wchodzące w skład organu wykonującego budżet lub plan finansowy jednostki sektora finansów publicznych albo organu zarządzającego podmiotu niezaliczanego do sektora finansów publicznych, któremu przekazano do wykorzystania lub dysponowania środki publiczne, lub zarządzającego mieniem tych jednostek lub podmiotów,

- kierowników jednostek sektora finansów publicznych,

- pracowników jednostek sektora finansów publicznych lub inne osoby, którym odrębną ustawą lub na jej podstawie powierzono wykonywanie obowiązków w takiej jednostce,

- osoby wykonujące w imieniu podmiotu niezaliczanego do sektora finansów publicznych, któremu przekazano do wykorzystania lub dysponowania środki publiczne, czynności związane z wykorzystaniem tych środków lub dysponowaniem tymi środkami.

Ustawa z dnia 27 sierpnia 2009 r. o finansach publicznych, Dz. U. 2009, nr 157 poz. 1240.

60 System odpowiedzialności za naruszenie dyscypliny finansów publicznych. Analiza funkcjonowania i propozycje zmian, Kancelaria Prezesa Rady Ministrów, Warszawa, 19 III 2010, s. 10.

61 D. Hajdys, Naruszenie dyscypliny finansów publicznych jako przejaw patologii w finansach publicznych, [w:] Patologie w administracji publicznej, red. P. Suwaj, D. Kijowski, Warszawa 2009, s. 702.

62 L. Lipiec-Warzecha, Zakres odpowiedzialności za naruszenie dyscypliny finansów publicznych, [online] http://finansepubliczne.bdo.pl/component/content/article/163.pdf, 20 IV 2014.

63 Wyrok Naczelnego Sądu Administracyjnego w Warszawie z dnia 21 stycznia 2003 r., sygn. III SA 417/01. 
Katalog czynów lub zaniechań stanowiących naruszenie dyscypliny finansów publicznych jest okazały (art. od 5 do 18$)^{64}$. Naruszeniem dyscypliny jest np. nieustalenie i niepobranie należności Skarbu Państwa, niewłaściwe przydzielenie i rozliczenie dotacji, dokonywanie zmian w planie finansowym jednostki bez stosownej legitymacji prawnej, dokonanie wydatku ze środków publicznych bez upoważnienia określonego ustawą budżetową, nieopłacenie składek na ubezpieczenia społeczne i składki chorobowej, zaciągnięcie zobowiązania bez upoważnienia określonego ustawą budżetową czy złamanie przepisów ustawy o zamówieniach publicznych. Naruszeniem dyscypliny jest również niewypełnienie obowiązku związanego z utworzeniem stanowiska audytora wewnętrznego w jednostce oraz niewykonanie lub nienależyte wykonanie przez kierownika jednostki sektora finansów publicznych obowiązków w zakresie kontroli zarządczej.

Na mocy art. 19 odpowiedzialność za naruszenie dyscypliny finansów publicznych ponosi osoba, która popełniła czyn naruszający dyscyplinę finansów publicznych określony przez ustawę obowiązującą w czasie jego popełnienia oraz można jej przypisać winę w czasie naruszenia dyscypliny ${ }^{65}$. Odpowiedzialność ponosi również osoba, która wydała polecenie wykonania czynu naruszającego dyscyplinę finansów publicznych. Nieświadomość tego, że podejmowane działanie lub zaniechanie działania stanowi naruszenie dyscypliny finansów publicznych, nie wyłącza odpowiedzialności, chyba że nieświadomość była usprawiedliwiona.

Nie stanowi naruszenia dyscypliny finansów publicznych działanie lub zaniechanie, którego przedmiotem są środki finansowe w wysokości nieprzekraczającej kwoty minimalnej, tj. kwoty przeciętnego wynagrodzenia miesięcznego w gospodarce narodowej w roku poprzednim, ogłoszonego przez Prezesa Głównego Urzędu Statystycznego ${ }^{66}$. Odpowiedzialności nie ponosi również osoba, która naruszyła dyscyplinę finansów publicznych wskutek wykonania polecenia przełożonego albo kierownika jednostki, albo dysponenta środków publicznych, organu nadzorującego lub organu założycielskiego, jeżeli przed wykonaniem polecenia zgłosiła pisemnie zastrzeżenie i - pomimo tego zastrzeżenia - otrzymała pisemne potwierdzenie wykonania polecenia albo polecenie nie zostało odwołane czy zmienione ${ }^{67}$.

64 Zob. szerzej o prawnych i systemowych uwarunkowaniach odpowiedzialności za naruszenie dyscypliny finansów publicznych: C. Kosikowski, Dyscyplina finansów publicznych oraz odpowiedzialność za jej naruszenie, [w:] Finanse publiczne i prawo finansowe, red. tenże, E. Ruśkowski, Warszawa 2007; C. Kosikowski, Z. Szpringer, Finanse publiczne. Komentarz do ustawy z dnia 26 listopada 1998 r., Zielona Góra 2000; C. Kosikowski, Odpowiedzialność za naruszenie dyscypliny finansów publicznych. Komentarz i przepisy, Warszawa 2000; L. Lipiec-Warzecha, Zakaz petnienia funkcji zwiazanych z dysponowaniem środkami publicznymi - uwagi de lege lata, [w:] Problemy stanowienia i stosowania prawa finansowego w krajach Europy Srodkowej i Wschodniej. Materiaty z konferencji naukowej w Grodnie w dniach 16-17 września 2006, Grodno 2006; taż, Ustawa o odpowiedzialności za naruszenie dyscypliny finansów publicznych. Komentarz, Warszawa 2012.

65 Nie można przypisać winy, jeżeli naruszenia nie można było uniknąć mimo dołożenia staranności wymaganej od osoby odpowiedzialnej za wykonanie obowiązku, którego niewykonanie lub nienależyte wykonanie stanowi czyn naruszający dyscyplinę finansów publicznych. Art. 19 ust. 2 Ustawy z dnia 17 grudnia 2004 r. o odpowiedzialności za naruszenie dyscypliny finansów publicznych.

66 Tamże, art. 26 ust. 3.

67 Tamże, art. 29 ust. 1. 
Omawiany rodzaj odpowiedzialności jest niezależny od odpowiedzialności określonej innymi przepisami prawa. Wyjątkiem są postępowania w sprawie o przestępstwo skarbowe, wykroczenie albo wykroczenie skarbowe, o czyn stanowiący równocześnie naruszenie dyscypliny finansów publicznych, na czas których zawiesza się postępowanie o naruszenie dyscypliny finansów publicznych. W przypadku prawomocnego skazania za powyższe przestępstwa lub wykroczenia postępowanie o naruszenie dyscypliny podlega umorzeniu.

Katalog sankcji za naruszenie dyscypliny finansów publicznych określony został $\mathrm{w}$ art. 31 omawianej ustawy. Zaliczono do niego: upomnienie, naganę, karę pieniężną oraz zakaz pełnienia funkcji związanych z dysponowaniem środkami publicznymi. Kara pieniężna określona została w przedziale od 0,25 do trzykrotności miesięcznego wynagrodzenia osoby odpowiedzialnej za naruszenie dyscypliny finansów publicznych ${ }^{68}$. Karę zakazu pełnienia funkcji związanych z dysponowaniem środkami publicznymi wymierza się na okres od roku do pięciu lat.

Skutki naruszenia dyscypliny finansów publicznych są istotne z punktu widzenia pracownika. Udzielenie kary w formie nagany lub kary pieniężnej powoduje określone skutki prawne, takie jak np. negatywna ocena kwalifikacyjna. Ukaranie zakazem pełnienia funkcji związanych z dysponowaniem środkami publicznymi uniemożliwia na zawarty w orzeczeniu okres pełnienie następujących funkcji: dyrektora generalnego, członka zarządu, skarbnika, głównego księgowego lub zastępcy głównego księgowego, kierownika lub zastępcy kierownika komórki bezpośrednio odpowiedzialnej za wykonywanie budżetu lub planu finansowego w jednostkach sektora finansów publicznych. Ponadto osoba taka nie może reprezentować interesów majątkowych Skarbu Państwa, jednostki samorządu terytorialnego lub innej jednostki sektora finansów publicznych, a także zasiadać w organach stanowiących, nadzorczych i wykonawczych państwowych i samorządowych osób prawnych ${ }^{69}$. Na marginesie prowadzonych rozważań należy stwierdzić, że zupełnie niezrozumiałe wydaje się pozostawienie możliwości kandydowania w wyborach samorządowych na stanowiska: wójta, burmistrza czy prezydenta miasta.

Jak widać, katalog kar został uszeregowany według wzrastającego stopnia uciążliwości dla osoby obwinionej. Każdorazowo organ orzekający wymierza karę, uwzględniając stopień szkodliwości naruszenia dyscypliny finansów dla finansów publicznych, stopień winy, a także uwzględniając cele kary w zakresie społecznego oddziaływania oraz cele zapobiegawcze i dyscyplinujące, które powinny być osiągnięte w stosunku do ukaranego. W przypadku niskiego stopnia szkodliwości czynu dla finansów publicznych istnieje możliwość wyznaczenia sprawcy najłagodniejszego wymiaru kary w postaci upomnienia ${ }^{70}$.

Organami orzekającymi w sprawach o naruszenie dyscypliny finansów publicznych pierwszej instancji są komisje orzekające w sprawach o naruszenie dyscypliny finansów publicznych oraz Główna Komisja Orzekająca w Sprawach o Naruszenie Dyscypliny

68 Tamże, art. 31 ust. 2.

69 Tamże, art. 32.

70 L. Lipiec-Warzecha, Czy zawsze naruszenie dyscypliny finansowej jest szkodliwe dla finansów publicznych, [online] http://finansepubliczne.bdo.pl/component/content/article/163.pdf, 11 II 2015. 
Finansów Publicznych. W pierwszej instancji orzekają: resortowe komisje orzekające o naruszenie dyscypliny finansów publicznych przy ministrach lub przewodniczących komitetów wchodzących w skład Rady Ministrów oraz komisja orzekająca przy Prezesie Rady Ministrów, a także komisje przy regionalnych izbach obrachunkowych. Instancję odwoławczą stanowi Główna Komisja Orzekająca.

W doktrynie i orzecznictwie dotyczącym odpowiedzialności za naruszenie dyscypliny finansów publicznych nie ma jednolitego stanowiska co do charakteru tego rodzaju odpowiedzialności. W orzecznictwie Głównej Komisji Orzekającej widoczne są różne linie interpretacyjne, od kwalifikowania odpowiedzialności za naruszenie dyscypliny finansów publicznych jako odpowiedzialności administracyjnej ${ }^{71}$, przez kar$n^{72}{ }^{72}$, a na dyscyplinarnej kończąc ${ }^{73}$. Doktryna rozróżnia natomiast odpowiedzialność: karną, karną skarbową, dyscyplinarną, administracyjną, cywilną, odpowiedzialność na podstawie prawa pracy (i innych pragmatyk zawodowych), a także administracyjno-karną ${ }^{74}$. W tym kontekście odpowiedzialność za naruszenie dyscypliny finansów publicznych ma charakter hybrydowy, łączący elementy odpowiedzialności karnej, administracyjnej i pracowniczej. Zdaniem autora w świetle wątpliwości interpretacyjnych winno się uporządkować prawnie charakter odpowiedzialności, gdyż może mieć to negatywne skutki zwłaszcza w odniesieniu do osób posiadających immunitet i odpowiadających w procedurze karnej ${ }^{75}$.

Osoby ukarane za naruszenie dyscypliny finansów publicznych wpisywane są do rejestru osób odpowiedzialnych za tego rodzaju naruszenia. Rejestr prowadzony jest przez Główną Komisję, do której przekazywane są prawomocne orzeczenia o odpowiedzialności za naruszenie dyscypliny finansów publicznych.

W 2012 r. do komisji orzekających w pierwszej instancji wpłynęło 1306 wniosków o ukaranie, a 468 oczekiwało na rozstrzygnięcie ${ }^{76}$. Komisje wydały ponad 1500 rozstrzygnięć, w tym 1249 orzeczeń wobec obwinionych (28,2\% osób obwinionych uniewinniono, pozostałe $71,8 \%$ uznano za odpowiedzialne za naruszenie dyscypliny finansów publicznych ${ }^{77}$. Spośród 897 osób ukarano 416, tj. 46\%. Najczęstszymi karami orzeczonymi w 2012 r. były: kara upomnienia (367 osób - 88,2\% ukaranych) i nagana (42 osoby - 10,1\% ukaranych). Karą pieniężną ukarano siedem osób (1,7\%

71 Zob. Orzeczenie Głównej Komisji Orzekającej z dnia 29 listopada 2007 r., sygn. DF/GKO$-4900-64 / 68 / 07 / 2818$, „Biuletyn orzecznictwa w sprawach o naruszenie dyscypliny finansów publicznych" 2008, nr 2, s. 99-108.

72 Por. Orzeczenie Głównej Komisji Orzekającej z dnia 12 września 2002 r., sygn. DF/GKO/Odw. -110/143/2002, opublikowane w LEX 79994.

73 Por. Orzeczenie Głównej Komisji Orzekającej z dnia 3 czerwca 2002 r., sygn. DF/GKO/Odw. -188/278/2001, opublikowane w LEX 80026.

74 System odpowiedzialności..., s. 10.

75 Zob. szerzej: A. Kościńska-Paszkowska, T. Bolek, Odpowiedzialność za naruszenie dyscypliny finansów publicznych - zmiana ustawy, „Kontrola Państwowa” 2012, nr 2, s. 164 i nast.

76 Zbiorcze sprawozdanie Gtównej Komisji Orzekającej za 2012 r., s. 16-17, [online] http://www.mf.gov. pl/documents/764034/1396184/sprawozdanie_GKO_2012.pdf, 11 II 2015.

77 Tamże, s. 20-22. 
ukaranych), zaś zakazem zajmowania stanowisk kierowniczych nie ukarano żadnego obwinionego $^{78}$.

Odpowiedzialność ustanowiona omawianą ustawą w odniesieniu do służby cywilnej ciąży przede wszystkim na dyrektorach generalnych urzędów, dyrektorach posiadających upoważnienia do dysponowania środkami publicznymi, a także pracownikach, którym powierzono obowiązki w zakresie gospodarki finansowej i materiałowej. Jak pokazują powyższe dane, zakres nieprawidłowości nie jest znaczący w kontekście liczby osób i działań związanych z gospodarką finansową prowadzonych przez poszczególne jednostki. Z doświadczeń autora wynika, że częstą przyczyną wszczynania postępowań jest niejasność przepisów prawnych oraz brak jednolitych wytycznych dotyczących ich stosowania. Przykładem takiej rozbieżności interpretacyjnej jest opłacanie podatku od towarów i usług związanych z podnoszeniem kwalifikacji zawodowych pracowników. Część urzędników, nie znając szczegółowych wytycznych dotyczących wydatków strukturalnych i zasad związanych ze zwolnieniami od podatku, łamie nieświadomie zapisy ustawy. Problematyczna w stosowaniu jest również Ustawa o zamówieniach publicznych. Urzędnicy, obawiając się postępowań przed komisją orzekającą w sprawach o naruszenie dyscypliny finansów publicznych, stosują uproszczone kryteria oceny ofert, które w następstwie uniemożliwiają wybranie najkorzystniejszej oferty. Należy dążyć do uproszczenia wewnętrznych procedur i przepisów prawa, tak aby środki publiczne były wydatkowane racjonalnie i gospodarnie. W przypadku przetargów istotnych ze względów bezpieczeństwa państwa, zarówno politycznego, jak i gospodarczego, powinny być one prowadzone przez specjalne zespoły powołane spośród najlepszych specjalistów od zamówień publicznych zatrudnionych w całej administracji. Takie podejście z jednej strony pozwoli na zarządzanie wiedzą funkcjonującą w strukturach administracji, z drugiej zaś na zapewnienie wysokiego poziomu profesjonalizmu w prowadzonych działaniach.

\section{ODPOWIEDZIALNOŚĆ MAJĄTKOWA ZA RAŻĄCE NARUSZENIE PRAWA}

Odpowiedzialność majątkowa za rażące naruszenie prawa jest kolejnym rodzajem reżimu prawnego odnoszącego się do funkcjonariuszy publicznych, w tym członków korpusu służby cywilnej zajmujących w szczególności samodzielne i kierownicze stanowiska. W dniu 20 stycznia 2011 r. parlament uchwalił Ustawę o odpowiedzialności majątkowej funkcjonariuszy publicznych za rażące naruszenie prawa ${ }^{79}$. Ustawa ta jest z pewnością jedną z bardziej kontrowersyjnych regulacji prawnych dotyczących urzędników ostatnich lat. Prace nad nią prowadzone były przez parlamentarzystów kolejnych kadencji. Zarówno w okresie poprzedzającym przygotowanie założeń do ustawy, jak i w trakcie prac parlamentarnych toczyła się ożywiona dyskusja nad potrzebą rozszerze-

Tamże, s. 22-28.

79 Ustawa z dnia 20 stycznia 2011 r. o odpowiedzialności majątkowej funkcjonariuszy publicznych za rażące naruszenie prawa, Dz.U. 2011, nr 34, poz. 173. 
nia obowiązujących dotychczas przepisów prawa regulujących kwestię odpowiedzialności majątkowej (materialnej) urzędników administracji publicznej, związanej z ich działalnością zawodowąa .

W odniesieniu do powyższej ustawy formułowano zastrzeżenia natury ogólnej. W szczególności wykazywano, że opiera się ona na błędnym założeniu, że w dotychczasowym stanie prawnym nie istnieją wystarczające możliwości dochodzenia od urzędników winnych powstania szkody roszczeń regresowych w razie zapłaty odszkodowania przez Skarb Państwa lub jednostkę samorządu terytorialnego ${ }^{81}$. Krajowa Rada Sądownicza wskazywała, że przedstawiony do zaopiniowania projekt zawierał wiele wad i nieścisłości ${ }^{82}$. Dotyczyły one m.in. „zamętu terminologicznego” oraz niespójności przepisów w kontekście norm prawa administracyjnego i ordynacji podatkowej ${ }^{83}$.

W uzasadnieniu do ustawy możemy przeczytać, że:

[...] wykonujac prawo, aparat administracyjny zbyt często dziata z jego naruszeniem. Przez wadliwe rozstrzygnięcia, dziatania podejmowane poza postępowaniem administracyjnym lub nieuzasadniona bierność urzędnicy wyrzadzaja obywatelom, $w$ tym i przedsiębiorcom wymierne, niejednokrotnie bardzo poważne, szkody. W najbardziej drastycznych przypadkach dochodzi do spektakularnych bankructw i likwidacji setek miejsc pracy. Dalsza konsekwencja tego stanu rzeczy jest oczywisty uszczerbek na autorytecie państwa i jego instytucji. Lekceważone przez funkcjonariuszy publicznych prawo nie znajduje tak$\dot{z}$ e zrozumienia i aprobaty w spoteczeństwie. W coraz więsszym stopniu wiąze się to takize zodpowiedzialnościa cywilna Skarbu Państwa i jednostek samorządu terytorialnego, które zmuszone są naprawiać wyrzadzone obywatelom i przedsiębiorcom szkody ${ }^{84}$.

Celem ustawy było również zahamowanie i odwrócenie niekorzystnych trendów związanych z działalnością funkcjonariuszy publicznych. Założono, że mechanizmem

80 Zob. szerzej: A. Stelmach-Młynarska, Rażace naruszenie prawa jako przestanka odpowiedzialności majątkowej funkcjonariuszy publicznych, „Monitor Ubezpieczeniowy” 2012, nr 49, [online] http://rzu. gov.pl/publikacje/artykuly-pracownikow-i-wspolpracownikow/Anna_Stalmach_Mlynarska__Razace_naruszenie_prawa_jako_przeslanka_odpowiedzialnosci_majatkowej_funkcjonariuszy_publiczny_21009, 12 IV 2015; E. Bagińska, Odpowiedzialność funkcjonariuszy publicznych za rażące naruszenie prawa w świetle projektu ustawy o szczególnych zasadach odpowiedzialności funkcjonariuszy publicznych za rażace naruszenie prawa, "Zeszyty Prawnicze” 2009, nr 1, s. 173-182; M. Ślifirczyk, $O$ projekcie ustawy o szczególnych zasadach odpowiedzialności funkcjonariuszy publicznych za rażace naruszenie prawa, „Zeszyty Prawnicze” 2009, nr 1, s. 183-193; R. Szczepaniak, Odpowiedzialność majątkowa urzędników - czy niezbędna jest nowa regulacja prawna?, „Finanse Komunalne” 2009, $\mathrm{nr}$ 5, s. 5-11; R. Szarek, Czy odpowiedzialność majątkowa urzędników powinna mieć nowe uregulowanie prawne?, „Samorząd Terytorialny” 2010, nr 3, s. 74-79.

E. Bagińska, Odpowiedzialność funkcjonariuszy..., s. 173.

82 S. Dąbrowski, Opinia Krajowej Rady Sadownictwa z dnia 9 grudnia 2008 r. w przedmiocie poselskiego projektu ustawy o szczególnych zasadach odpowiedzialności funkcjonariuszy publicznych za rażace naruszenie prawa, druk nr 1407, Warszawa, 10 XII 2008, [online] http://orka.sejm.gov.pl/Druki6ka. nsf/0/CC5A629F35ED310CC12575270043F51D/\$file/1407-001.pdf, 12 IV 2015.

83 Tamże.

84 Uzasadnienie do poselskiego projektu Ustawy o szczególnych zasadach odpowiedzialności funkcjonariuszy publicznych za rażace naruszenie prawa, druk nr 1407, [online] http://orka.sejm.gov.pl/Druki6ka. nsf, 12 IV 2015. 
skutecznie zapobiegającym wynaturzeniom w funkcjonowaniu administracji będzie przede wszystkim sprawne i nieuchronne obciążanie urzędników, przynajmniej w ograniczonym zakresie, materialnymi skutkami ich działań niezgodnych z prawem. Poselski projekt ustawy zyskał aprobatę Rady Ministrów i został uchwalony przez parlament. Aprobujące stanowisko do projektu wyrazili również przedstawiciele sektora prywatnego. Krajowa Izba Gospodarcza podkreślała, że ustawa ma szansę przyczynić sie do poprawy bezpieczeństwa obrotu gospodarczego, zmniejszając liczbę btędnych decyzji administracyjnych i ograniczając korupcje ${ }^{85}$. Jak pisał Andrzej Adamczyk, z uwagi na konieczność ochrony stanu finansów publicznych podmiotów wtadzy publicznej, odpowiedzialnych cywilnoprawnie za szkody wyrzadzone przez niezgodne z prawem dziatanie organów wtadzy publicznej w szerokim zakresie na zasadzie ryzyka (art. 77 ust. 1 Konstytucji RP), należy uznać zasadność takiego kierunku legislacji, ale powotana ustawa nie wydaje się wprowadzać adekwatnych mechanizmów dochodzenia roszczeń regresowych. Można wręcz postawić teze, że ustawa ta wpisuje się w nurt dziatań prawotwórczych o dużej sile oddziatywania medialnego, nierozwiazujacych jednak istotnych problemów praw$n y c h^{86}$. W tezie tej jest duża doza prawdopodobieństwa, zwłaszcza w odniesieniu do krótkoterminowych celów przyświecających politykom.

W art. 1 omawianej ustawy określono zasady odpowiedzialności majątkowej funkcjonariuszy publicznych wobec Skarbu Państwa, jednostek samorządu terytorialnego lub innych podmiotów ponoszących odpowiedzialność za szkodę wyrządzoną przy wykonywaniu władzy publicznej, za działania lub zaniechania prowadzące do rażącego naruszenia prawa oraz zasady postępowania w przedmiocie takiej odpowiedzialności. Mianem funkcjonariusza publicznego określono osobę działającą w charakterze organu administracji publicznej lub z jego upoważnienia albo jako członek kolegialnego organu administracji publicznej lub osobę wykonującą w urzędzie organu administracji publicznej pracę w ramach stosunku pracy, stosunku służbowego lub umowy cywilnoprawnej, biorącą udział w prowadzeniu sprawy rozstrzyganej w drodze decyzji lub postanowienia przez taki organ ${ }^{87}$. $\mathrm{Z}$ zakresu definicyjnego wynika wprost, że odpowiedzialności majątkowej za rażące naruszenie prawa podlega znaczna liczba pra-

85 Krajowa Izba Gospodarcza, Zasady odpowiedzialności funkcjonariuszy publicznych, Warszawa, 30 XI 2010, [online] http://www.kig.pl/informacje-prasowe/2210-zasady-odpowiedzialnosci-funkcjonariuszy-publiczny.html 12 II 2015.

86 A. Adamczyk, Zakres przedmiotowy odpowiedzialności majątkowej funkcjonariuszy publicznych za rażace naruszenie prawa, [online] http://m.ksiegarnia.lexisnexis.pl/gfx/lexisnexis/userfiles/files/zakres_przedmiotowy_odpowiedzialnosci_majatkowej_funkcjonariuszy_publicznych_za_razace_naruszenie_prawa.pdf, 12 IV 2015.

87 Art. 2 ust. 1 pkt. 1 Ustawy z dnia 20 stycznia 2011 r. o odpowiedzialności majątkowej funkcjonariuszy publicznych za rażące naruszenie prawa. Niezbędną przesłanką do uznania wskazanych osób za funkcjonariuszy publicznych w rozumieniu ustawy jest przypisanie im udziału w prowadzeniu sprawy, która była przez organ administracji publicznej rozstrzygana w drodze decyzji lub postanowienia. Przez branie udziału w prowadzeniu sprawy należy rozumieć czynności, jakie funkcjonariusz publiczny wykonuje w imieniu organu administracji publicznej w związku ze sprawą, a więc wszystkie czynności procesowe, np. zawiadomienie stron o wszczęciu postępowania administracyjnego, zbieranie dowodów czy prowadzenie rozprawy administracyjnej, za: Ł. Jędruszuk, Odpowiedzialność majątkowa funkcjonariuszy publicznych za rażace naruszenie prawa - analiza praktyczna, „Temidium” 2011, nr 2, s. 35. 
cowników i urzędników służby cywilnej uczestniczących w procesach wydawania decyzji administracyjnych.

Zgodnie z art. 5 ustawy funkcjonariusz publiczny ponosi odpowiedzialność majątkową $\mathrm{w}$ razie łącznego zaistnienia następujących przesłanek:

- na mocy prawomocnego orzeczenia sadu lub na mocy ugody zostato wyptacone przez podmiot odpowiedzialny odszkodowanie za szkodę wyrządzona przy wykonywaniu wtadzy publicznej z rażacym naruszeniem prawa,

- rażace naruszenie prawa zostato spowodowane zawinionym dziataniem lub zaniechaniem funkcjonariusza publicznego,

- rażace naruszenie prawa zostato stwierdzone zgodnie $z$ artykutem 6 ustawy precyzujacym formy, w jakich następuje ustalenie jednej z przestanek odpowiedzialności majatkowej funkcjonariusza. Ustalenie (stwierdzenie) przestanki w postaci rażącego naruszenia prawa może nastąić jedynie $w$ formach (orzeczeniach) wymienionych w punktach 1-11 artykutu $6^{88}$.

Orzeczenia te dotyczą m.in.: wydania ostatecznej decyzji stwierdzającej nieważność decyzji lub postanowienia na podstawie Kodeksu postępowania administracyjnego, wydania ostatecznej decyzji stwierdzającej nieważność decyzji lub postanowienia na podstawie przepisów Ordynacji podatkowej ${ }^{89}$, stwierdzenia braku podstawy prawnejej lub rażącego naruszenia prawa ${ }^{91}$ na podstawie ustawy Prawo o postępowaniu przed sądami administracyjnymi ${ }^{92}$, prawomocnego stwierdzenia rażącego naruszenia prawa na podstawie Kodeksu postępowania cywilnego ${ }^{93}$ oraz stwierdzenia braku podstawy prawnej lub rażącego naruszenia prawa na podstawie Ustawy o ochronie konkurencji i konsumentów ${ }^{94}$.

Na kierownika jednostki wypłacającej odszkodowanie pod groźbą odpowiedzialności karnej nałożono obowiązek złożenia do prokuratury okręgowej wniosku o przepro-

88 Zob. szerzej: B. Rakoczy, A. Matan, Komentarz do art. 6, [w:] Odpowiedzialność majątkowa funkcjonariuszy publicznych za rażace naruszenie prawa. Komentarz, red. A. Bielska-Brodziak, Warszawa 2011, s. 298 i nast.; B. Rakoczy, Ustawa o odpowiedzialności majątkowej funkcjonariuszy publicznych. Komentarz, Warszawa 2012, s. 77 i nast.

89 Ustawa z dnia 29 sierpnia 1997 r. Ordynacja podatkowa, Dz.U. 2005, nr 8, poz. 60, z późn. zm.

90 Jak wskazuje J. Borkowska: znaczenie pojęcia „decyzja wydana bez podstawy prawnej” jest jednoznaczne, bo albo nie ma przepisu prawnego, który umocowuje administrację publiczna do dziatania, albo też przepis jest, ale nie spetnia wymagań podstawy prawnej dziatania organów tej administracji, polegającego na wydawaniu decyzji administracyjnych i postanowien, rozumianych jako indywidualne akty administracyjne zewnętrzne. J. Borkowska, Odpowiedzialność majątkowa funkcjonariuszy publicznych za rażące naruszenie prawa, [online] http://www.ekspertbeck.pl/odpowiedzialnosc-majatkowa-funkcjonariuszy-publicznych-za-razace-naruszenie-prawa, 12 IV 2015.

91 Tamże. O rażącym naruszeniu prawa decydują łącznie trzy przesłanki: oczywistość naruszenia prawa, charakter przepisu, który został naruszony, oraz racje ekonomiczne lub gospodarcze - czyli skutki, jakie wywołuje decyzja.

92 Ustawa z dnia 30 sierpnia 2002 r. Prawo o postępowaniu przed sądami administracyjnymi, Dz.U. 2002, nr 153, poz. 1270 , z późn. $z$ m.

93 Ustawa z dnia 17 listopada 1964 r. Kodeks postępowania cywilnego, Dz.U. 1964, nr 43, poz. 296, z późn. zm.

94 Ustawa z dnia 16 lutego 2007 r. o ochronie konkurencji i konsumentów, Dz.U. 2007, nr 50, poz. 331, z późn. $\mathrm{zm}$. 
wadzenie postępowania wyjaśniającego ${ }^{95}$. Postępowanie prowadzone jest na podstawie Ustawy o prokuraturze ${ }^{96}$. W przypadku stwierdzenia winy funkcjonariusza publicznego ustalane jest odszkodowanie, którego wysokość nie może przewyższać dwunastokrotności miesięcznego wynagrodzenia przysługującego urzędnikowi. W przypadku działania lub zaniechania przez kilku funkcjonariuszy ponoszą oni odpowiedzialność solidarnie i proporcjonalnie do poziomu winy.

Scharakteryzowana pokrótce ustawa budzi szereg wątpliwości wśród teoretyków i praktyków, którzy na co dzień zajmują się administracją publiczną. Andrzej Adamczyk twierdzi, że instytucja odpowiedzialności majatkowej funkcjonariuszy publicznych powinna być oparta na obiektywnym kryterium, jakim jest zawinione naruszenie prawa97. Zdaniem Michała Kuleszy ustawa powinna dotyczyć odpowiedzialności urzędników w zakresie wszystkich wtadczych przejawów dziatania wtadzy publicznej (imperium) oraz zaniechań w tym zakresie. Nic nie uzasadnia innego traktowania deliktów urzędniczych w sferze wydawania decyzji administracyjnych, przy przygotowaniu projektów aktów generalnych (także projektów ustaw - „lub czasopisma”), czy w zwiazku z podejmowaniem czynności faktycznych rodzacych skutki prawne ${ }^{98}$.

Ustawodawca założył, że w wyniku przyjęcia ustawy znacząco spadnie liczba rażących naruszeń prawa, w tym rozstrzygnięć administracyjnych wydawanych z naruszeniem prawa. Założono również wzrost zaufania obywateli do organów administracji publicznej, a w konsekwencji także szacunek dla instytucji państwowych w ogóle, jak również wobec praworządności. Istotnym pozytywnym zmianom ulec miały warunki prowadzenia działalności gospodarczej, co miało przyczynić się do dalszego rozwoju przedsiębiorczości ${ }^{99}$. Na dziś trudno jest jednoznacznie ocenić, czy te założenia zostały spełnione. Poziom zaufania do urzędników i funkcjonariuszy publicznych nadal jest bardzo niski. Przedsiębiorcy prowadzący działalność gospodarczą stale borykają się z utrudnieniami związanymi z działalnością urzędniczą, a liczba wadliwych decyzji z całą pewnością nie zmieniła się diametralnie.

Statystykę skuteczności wprowadzonego mechanizmu prawnego przedstawił na posiedzeniu Komisji Administracji i Cyfryzacji Wojciech Hajduk. Zaprezentował on dane dotyczące postępowań toczących się w sądach powszechnych w 2012 r. przeciwko Skarbowi Państwa, a także liczby postępowań, w których roszczenia uwzględniono ${ }^{100}$.

95 Art. 7 ust. 1 Ustawy z dnia 20 stycznia 2011 r. o odpowiedzialności majątkowej funkcjonariuszy publicznych za rażace naruszenie prawa.

96 Ustawa z dnia 20 czerwca 1985 r. o prokuraturze, Dz.U. 2008, nr 7, poz. 39, z późn. zm.

97 A. Adamczyk, Odpowiedzialność...

98 M. Kulesza, Opinia odnośnie do poselskiego projektu ustawy o szczególnych zasadach odpowiedzialności funkcjonariuszy publicznych za naruszenie prawa i o zmianie innych ustaw, druk sejmowy nr 3484, Warszawa, 31 XII 2004, s. 2, [online] http://orka.sejm.gov.pl/proc4.nsf/opisy/3484.htm, 12 II 2015.

99 Uzasadnienie do poselskiego projektu Ustawy o szczególnych zasadach odpowiedzialności funkcjonariuszy publicznych za rażące naruszenie prawa, druk nr 1407, [online] http://orka.sejm.gov.pl/Druki6ka. nsf, 12 II 2015.

100 Na poziomie sądów rejonowych, jako sądów pierwszej instancji, zakończono przeciwko Skarbowi Państwa 3260 spraw ze wszystkich kategorii, z tego uwzgledniono roszczenia w 214 sprawach, a $w 9$-zawarto ugo- 
Jak to podkreślił minister, ustawowe przesłanki odpowiedzialności bardzo zawężają liczbę postępowań. Zastępca prokuratora generalnego potwierdził, że na dzień 27 czerwca 2013 r. nie odnotowano prowadzenia postępowań wyjaśniających, w efekcie których prokurator wystąpiłby z pozwem regresowym, nie odnotowano także postępowań karnych w oparciu o Ustawę o odpowiedzialności majątkowej funkcjonariuszy publicznych ${ }^{101}$. Dane te pokazują nieskuteczność przyjętego mechanizmu odpowiedzialności.

\section{ODPOWIEDZIALNOŚĆ MATERIALNA}

Ostatnim z omawianych reżimów odpowiedzialności dotyczących relacji pracowniczych, w tym członków korpusu służby cywilnej, jest odpowiedzialność materialna (określana również mianem cywilnej ${ }^{102}$ lub majątkowej) pracowników wynikająca z przepisów Kodeksu pracy ${ }^{103}$ i częściowo Kodeksu cywilnego ${ }^{104}$. Ten rodzaj odpowiedzialności nie jest szczególnym rygorem dotyczącym wyłącznie pracowników administracji publicznej ${ }^{105}$. Jest on obecny w relacjach kształtujących obowiązki i uprawnienia pracowników niezależnie od charakteru prawnego pracodawcy. Odpowiedzialność materialna obejmuje obowiązek naprawienia szkody wyrządzonej przez pracownika przy wykonywaniu powierzonych mu obowiązków. Praktyczne problemy wynikające z wprowadzenia przepisów o odpowiedzialności materialnej skłoniły Sąd Najwyższy do wydania wytycznych dla wymiaru sprawiedliwości i praktyki sądowej w przedmiocie materialnej odpowiedzialności pracowników ${ }^{106}$. Mimo upływu czasu zasadnicze tezy wygłoszone przez Sąd Najwyższy są nadal aktualne i stosowane w praktyce orzeczniczej.

dę, czyli w kilku procentach. Na poziomie sądów okregowych, jako sądów pierwszej instancji, zakończono postępowania w prawie 3700 sprawach, przy czym roszczenia uwzględniono w 312 sprawach, a w 11 zawarto ugodę. Chcępaństwu uzmystowić, że te dane przedstawiaja sprawy, w których zasądzono roszczenia od Skarbu Państwa ze wszystkich możliwych podstaw, tzn. również w tych sprawach, gdzie dziatanie pracownika lub funkcjonariusza byto niezawinione, a także nie byto rażacego naruszenia prawa. W. Hajduk, wypowiedź na posiedzeniu Komisji Administracji i Cyfryzacji w dniu 25 września 2013 r., [online] http://www.sejm.gov.pl/sejm7.nsf/biuletyn.xsp?documentId=880D1A51634C7304C1257BF6004B1F4E, 13 II 2015.

101 Tamże.

102 Np. E. Ura, Prawo urzędnicze..., s. 224.

103 Ustawa z dnia 26 czerwca 1974 r. Kodeks pracy, Dz.U. 1974, nr 24, poz. 141, z późn. zm.

104 Ustawa z dnia 23 kwietnia 1964 r. Kodeks cywilny, Dz.U. 1964, nr 16, poz. 93.

105 Zob. szerzej na temat odpowiedzialności majątkowej pracowników: Kodeks pracy. Komentarz, red. W. Muszalski, Warszawa 2013; W. Putalski, Odpowiedzialność materialna pracowników, Gdańsk 1999; tenże, Pracownicza odpowiedzialność odszkodowawcza. Praktyczny komentarz dla pracodawców, Warszawa 2006; S. Garlicki, M. Piekarski, A. Stelmachowski, Odpowiedzialność cywilna za niedobory (manka), Warszawa 1962.

106 Uchwata petnego sktadu Izby Pracy i Ubezpieczeń Spotecznych z dnia 29 grudnia 1975 r., V PZP 13/75 wytyczne wymiaru sprawiedliwości i praktyki sądowej w przedmiocie materialnej odpowiedzialności pracowników, „Orzecznictwo Sądu Najwyższego - Izba Cywilna/Pracy” 1976, z. 2, poz. 19. 
Wprowadzenie zapisów związanych z odpowiedzialnością materialną pracowników wynikało ze specyficznych cech odnoszących się do tego rodzaju sytuacji, w których stosowanie ogólnych reguł odszkodowawczych okazywało się nieadekwatne i wymagające odrębnej regulacji ${ }^{107}$. Stosowanie przepisów Kodeksu pracy odnoszących się do odpowiedzialności materialnej ma charakter bezwzględny i zostało oparte na zasadzie winy pracownika, uzależniając ją od stopnia i zakresu przewinienia. Odpowiedzialność materialna pracowników podzielona została ze względu na jej zakres przedmiotowy. I tak - w świetle Kodeksu pracy - mamy do czynienia z odpowiedzialnością pracowników za szkodę wyrządzoną pracodawcy (art. od 114 do 123) i odpowiedzialnością za mienie powierzone pracownikowi (art. od 124 do 127).

Artykuł 114 Kodeksu pracy stanowi, że pracownik, który wskutek niewykonania lub nienależytego wykonania obowiąków pracowniczych ze swej winy wyrządzit pracodawcy szkodę, ponosi odpowiedzialność materialna. Odpowiedzialność ponoszona jest za szkodę w granicach rzeczywistej straty poniesionej przez pracodawcę i tylko za normalne działania ${ }^{108}$ lub zaniechania, z których wynikła szkoda. Ograniczenie odpowiedzialności do rzeczywistej straty (damnum emergens) powoduje, że nie obejmuje ona korzyści, których pracodawca nie uzyskał (lucrum cessans). Warto jednak tu przypomnieć, że pracownik wyrządzający nieumyślnie szkodę pracodawcy może ponieść odpowiedzialność materialną do kwoty trzykrotnego miesięcznego wynagrodzenia. W przypadku działania umyślnego pracownik zobowiązany jest do naprawienia szkody w pełnej wysokości. Ciężar dowodowy związany z wykazaniem winy pracownika leży po stronie pracodawcy. Odpowiedzialność pracownika wyłączona jest w zakresie przyczynienia się pracodawcy lub innego pracownika do powstania szkody lub zwiększenia jej rozmiarów, a także w związku z ryzykiem prowadzenia działalności gospodarczej. Jak już było wspomniane, w przypadku wyrządzenia szkody przez kilku pracowników odpowiadają oni solidarnie w zakresie ponoszonego stopnia winy. Działanie lub zaniechanie pracownika powodujące szkodę dla osoby trzeciej rodzi odpowiedzialność wyłącznie wobec pracodawcy, który zobowiązany jest do naprawy szkody wobec osoby trzeciej. Pracodawca w trybie regresowym dochodzi następnie roszczeń wobec pracownika.

Drugim rodzajem odpowiedzialności materialnej jest odpowiedzialność za mienie powierzone pracownikowi. Pracownik, któremu powierzono (z obowiązkiem zwrotu albo rozliczenia się) pieniądze czy papiery wartościowe lub kosztowności oraz narzędzia i inne przedmioty niezbędne do wykonywania pracy, odpowiada w pełnej wysokości za szkodę powstałą w tym mieniu. Zwolnienie od odpowiedzialności możliwe jest w przypadku niezapewnienia przez pracodawcę warunków umożliwiających zabezpieczenie powierzonego mienia.

107 W. Muszalski, Odpowiedzialność materialna pracowników, [w:] Kodeks pracy. Komentarz, red. tenże, Warszawa 2013, s. 329.

108 Jak pisze W. Muszalski, normalne następstwa to takie, które przezorny i rozsądny pracownik mógtby przewidzieć jako skutek swego dziatania lub bezczynności. Tamże, s. 332. 


\section{PODSUMOWANIE}

Rekapitulując prowadzone rozważania dotyczące różnego rodzaju reżimów odpowiedzialności członków korpusu służby cywilnej, należy stwierdzić, że w przyszłości przed ustaleniem kolejnego typu odpowiedzialności urzędniczej warto dokonać audytu jakości funkcjonujących rozwiązań prawnych. Wiele problemów wynikających z praktyki urzędniczej powodowanych jest niską jakością stanowionego prawa. Na kwestię tę zwracają uwagę również niektórzy parlamentarzyści. Poseł Antoni Mężydło twierdzi, że w Polsce mamy bardzo skomplikowany system prawa. Jest on bardzo ztożony. Często gra pomiędzy urzędnikiem a prawnikami powoduje, że decyzja zostaje uznana za podjęta z rażacym naruszeniem prawa. Rażace naruszenie prawa jest instytucja dająca większe możliwości odwotawcze oraz pociagnięcie sprawy w prawidtowym kierunku dla zainteresowanego ${ }^{109}$.

Jeśli nałożymy na to tendencje „nadregulacyjne” poszczególnych ministrów, rozliczanych politycznie i społeczne za liczbę przygotowanych aktów prawnych, jawi się nam skomplikowana machina systemu prawnego i administracyjnego. Warto również pamiętać, że jakość urzędniczego wykonawstwa administracyjnego zależy w dużej mierze od jakości kadr urzędniczych. Poziom wynagrodzeń wielu urzędników realizujących istotny zakres władztwa publicznego odbiega znacząco od poziomu wynagrodzeń oferowanych tej klasy specjalistom w sektorze prywatnym. Taki stan rzeczy z pewnością nie przyczynia się do wzrostu zainteresowania podjęciem pracy w strukturach administracji publicznej, w tym w służbie cywilnej. $Z$ wykonywaniem istotnych zadań państwa musi łączyć się godziwy poziom wynagrodzenia oraz wysoka pozycja zawodowa oparta na zaufaniu społecznym wynikającym z profesjonalizmu i sprawności działania pracowników administracji rządowej. Do osiągnięcia tego celu jeszcze długa droga, jednak na pewno należy już rozpocząć poważną i długofalową dyskusję o przyczynach poszczególnych dysfunkcji aparatu państwowego.

Już w latach 70. XX w. Ewa Łętowska pisała, że ze społecznego punktu widzenia bardziej pożądane jest zapobieganie wyrządzaniu szkód niż naprawianie już wyrządzonych. Działalność prewencyjna jest więc ze społecznego punktu widzenia bardziej doniosła niż niwelowanie uszczerbku, jakiego doznał konkretny poszkodowany ${ }^{110}$. Witold Warkałło dodawał, że każda szkoda, nawet zrekompensowana, istnieje nadal, tyle że lokalizuje się w majątku podmiotu zobowiązanego do jej naprawienia ${ }^{111}$. Stwierdzenia te pomimo upływu wielu lat nadal zachowują swoją aktualność. Działania prewencyjne, jakie powinno podejmować państwo, można sprowadzić przede wszystkim do pozyskiwania wysokiej jakości kadr urzędniczych realizujących zadania publiczne, a także inwestowania w już zatrudnionych urzędników, aby stale podnosić ich poziom wiedzy specjalistycznej

109 A. Mężydło, wypowiedź na posiedzeniu Komisji Administracji i Cyfryzacji w dniu 25 września 2013 r., [online] http://www.sejm.gov.pl/sejm7.nsf/biuletyn.xsp?documentId=880D1A51634C7304C1257BF6004B1F4E, 13 III 2015.

110 E. Łętowska, Odpowiedzialność odszkodowawcza administracji, [w:] System prawa administracyjnego, t. 3, red. T. Rabska, J. Łętowski, Wrocław 1978, s. 462.

111 W. Warkałło, Odpowiedzialność odszkodowawcza. Funkcje, rodzaje, granice, Warszawa 1972, s. 14. 
i niezbędnych kompetencji. Na drugim biegunie należy postawić działania nakierowane na uproszczenie systemu prawnego oraz usuwanie istniejących barier organizacyjnych.

Należy również dodać, iż oprócz ustawowego katalogu obowiązku i praw urzędnicy posiadają jeszcze jeden - szczególny rodzaj prawa. Jest to prawo do popełnienia błędu w związku z wykonywaniem powierzonych zadań. Sądzę, że w tym stwierdzeniu zawarta jest istota toczącej się dyskusji o skuteczności lub nieskuteczności wdrażanych mechanizmów dyscyplinujących. Truizmem jest stwierdzenie, że błędów nie popełnia tylko ten, kto nic nie robi. W gąszczu przepisów prawnych i ich zawiłości należy się liczyć z ich popełnieniem. Wydaje się jednak, że urzędnicy powinni mieć poczucie, iż popełnienie nieumyślnego błędu nie będzie od razu sankcjonowane w dotkliwy sposób. Prowadzona od lat nagonka medialna i społeczna, a także polityczna w związku z popełnianymi przez nich błędami może bowiem spowodować, że urzędnicy nie będą podejmować trudnych i często także oczekiwanych społecznie decyzji. W konsekwencji wpłynąć to może na spadek sprawności działania aparatu administracyjnego państwa. Rygorystyczne sankcje związane z odpowiedzialnością powinny być domeną i punktem wyjścia dla działań celowych na szkodę i zawinionych przez urzędników. Problem celowego działania na szkodę obywateli lub w interesie danej grupy jest niewątpliwie obecny w funkcjonowaniu struktur administracji rządowej i powinno się zrobić wszystko, aby zjawisko to wyeliminować. Należy jednak pamiętać, by nie wprowadzać nieuzasadnionych generalizacji w ocenie tych działań, przyczyniając się tym samym do przysłowiowego wylewania dziecka z kąpielą.

\section{BIBLIOGRAFIA}

\section{Źródła}

Orzeczenie Głównej Komisji Orzekającej z dnia 12 września 2002 r., sygn. DF/GKO/Odw. -110/143/2002, opublikowane w LEX 79994.

Orzeczenie Głównej Komisji Orzekającej z dnia 29 listopada 2007 r., sygn. DF/GKO$-4900-64 / 68 / 07 / 2818$, „Biuletyn orzecznictwa w sprawach o naruszenie dyscypliny finansów publicznych" $2008, \mathrm{nr} 2$.

Orzeczenie Głównej Komisji Orzekającej z dnia 3 czerwca 2002 r., sygn. DF/GKO/Odw. -188/278/2001, opublikowane w LEX 80026.

Postanowienie Sądu Najwyższego z dnia 25 lutego 2003 r., sygn. WK 3/03, „Orzecznictwo Sądu Najwyższego - Izba Karna i Wojskowa" 2003, z. 5-6, poz. 53.

Rozporzadzenie Prezesa Rady Ministrów z dnia 9 kwietnia 2009 r. w sprawie postępowania wyjaśniającego i postępowania dyscyplinarnego w stużbie cywilnej, Dz.U. 2009, nr 60, poz. 493.

Rozporzadzenie Prezesa Rady Ministrów z dnia 9 kwietnia 2009 r. w sprawie wynagrodzenia cztonków Wyższej Komisji Dyscyplinarnej Stużby Cywilnej, komisji dyscyplinarnych oraz rzeczników dyscyplinarnych i ich zastępców, Dz.U. 2009, nr 60, poz. 492.

Sposób prowadzenia postępowania wyjaśniającego i dyscyplinarnego w stużbie cywilnej. Poradnik, Kancelaria Prezesa Rady Ministrów, Warszawa, listopad 2011.

Sprawozdanie Szefa Stużby Cywilnej o stanie stużby cywilnej i realizacji zadan tej stużby w 2009 roku, Kancelaria Prezesa Rady Ministrów, Warszawa, marzec 2010. 
Sprawozdanie Szefa Stużby Cywilnej o stanie stużby cywilnej i realizacji zadań tej stużby w 2010 roku, Kancelaria Prezesa Rady Ministrów, Warszawa, marzec 2011.

Sprawozdanie Szefa Stużby Cywilnej o stanie stużby cywilnej i realizacji zadań tej stużby w 2011 roku, Kancelaria Prezesa Rady Ministrów, Warszawa, marzec 2012.

Sprawozdanie Szefa Stużby Cywilnej o stanie stużby cywilnej i realizacji zadań tej stużby w 2012 roku, Kancelaria Prezesa Rady Ministrów, Warszawa, marzec 2013.

Sprawozdanie Szefa Stużby Cywilnej o stanie stużby cywilnej i realizacji zadań tej stużby w 2013 roku, Kancelaria Prezesa Rady Ministrów, Warszawa, marzec 2014.

Sprawozdanie Szefa Stużby Cywilnej o stanie stużby cywilnej i realizacji zadań tej stużby w 2014 roku. Zatącznik nr 9, Kancelaria Prezesa Rady Ministrów, Warszawa, marzec 2015.

Uchwata petnego sktadu Izby Pracy i Ubezpieczeń Spotecznych z dnia 29 grudnia 1975 r., V PZP 13/75 - wytyczne wymiaru sprawiedliwości i praktyki sądowej w przedmiocie materialnej odpowiedzialności pracowników, „Orzecznictwo Sądu Najwyższego - Izba Cywilna/Pracy” 1976, z. 2, poz. 19.

Ustawa z dnia 16 lutego 2007 r. o ochronie konkurencji i konsumentów, Dz.U. 2007, nr 50, poz. 331, z późn. zm.

Ustawa $z$ dnia 17 grudnia 2004 r. o odpowiedzialności za naruszenie dyscypliny finansów publicznych, Dz.U. 2013, nr 168.

Ustawa z dnia 17 listopada 1964 r. Kodeks postępowania cywilnego, Dz.U. 1964, nr 43, poz. 296, z późn. zm.

Ustawa z dnia 20 czerwca 1985 r. o prokuraturze, Dz.U. 2008, nr 7, poz. 39, z późn. zm.

Ustawa $z$ dnia 20 stycznia $2011 \mathrm{r}$. o odpowiedzialności majątkowej funkcjonariuszy publicznych za rażace naruszenie prawa, Dz.U. 2011, nr 34, poz. 173.

Ustawa z dnia 21 listopada 2008 r. o stużbie cywilnej, Dz.U. 2014, poz. 1111, z późn. zm.

Ustawa z dnia 23 kwietnia 1964 r. Kodeks cywilny, Dz.U. 1964, nr 16, poz. 93.

Ustawa z dnia 26 czerwca 1974 r. Kodeks pracy, Dz.U. 1974, nr 24, poz. 141, z późn. zm.

Ustawa $z$ dnia 26 listopada 2011 r. o zmianie ustawy - Kodeks karny oraz ustawy o Policji, Dz.U. 2011, nr 240, poz. 1602.

Ustawa z dnia 27 sierpnia 2009 r. o finansach publicznych, Dz.U. 2009, nr 157, poz. 1240.

Ustawa z dnia 29 sierpnia 1997 r. Ordynacja podatkowa, Dz.U. 2005, nr 8, poz. 60, z późn. zm.

Ustawa $z$ dnia 30 sierpnia 2002 r. Prawo o postępowaniu przed sadami administracyjnymi, Dz.U. 2002, nr 153, poz. 1270, z późn. zm.

Ustawa z dnia 5 sierpnia 2010 r. o ochronie informacji niejawnych, Dz.U. 2010, nr 182, poz. 1228.

Ustawa z dnia 6 czerwca 1997 r. Kodeks karny, Dz.U. 1997, nr 88, poz. 553, z późn. zm.

Wyrok Naczelnego Sądu Administracyjnego w Warszawie z dnia 21 stycznia 2003 r., sygn. III SA 417/01.

Wyrok Sądu Apelacyjnego w Szczecinie z dnia 11 grudnia 2012 r., sygn. III ZPo 5/12.

Wyrok Sądu Najwyższego - Izba Karna z dnia 5 listopada 1997 r., sygn. V KKN 105/97, „Orzecznictwo Izby Karnej i Wojskowej Sądu Najwyższego” 1998, z. 1-2, poz. 7.

Wyrok Sądu Najwyższego - Izba Wojskowa z dnia 8 listopada 1974 r., sygn. Rw 522/74, „Orzecznictwo Sądu Najwyższego - Wydawnictwo Prokuratury Generalnej” 1975, z. 2, poz. 20.

Wyrok Sądu Najwyższego z 29 lutego 1984 r., sygn. RW 53/84, „Orzecznictwo Sądu Najwyższego - Izba Karna i Wojskowa” 1984, z. 9-10, poz. 94. 
Wyrok Sądu Najwyższego z dnia 2 marca 1972 r., sygn. II KR 4/71, „Orzecznictwo Sądu Najwyższego - Wydawnictwo Prokuratury Generalnej” 1972, z. 2, poz. 156.

Wyrok Sądu Najwyższego z dnia z 17 września 1974 r., sygn. IV KR 191/74, „Orzecznictwo Sądu Najwyższego - Wydawnictwo Prokuratury Generalnej” 1975, nr 2, poz. 22.

Wyrok Trybunału Konstytucyjnego z dnia 9 czerwca 2010 r., sygn. SK 52/08, Dz.U.2010, nr 117 , poz. 790, „Orzecznictwo Trybunału Konstytucyjnego Zbiór Urzędowy”, nr 5/A/2010.

Zarzadzenie Nr 70 Prezesa Rady Ministrów z dnia 6 października 2011 r. w sprawie wytycznych $w$ zakresie przestrzegania zasad stużby cywilnej oraz $w$ sprawie zasad etyki korpusu stużby cywilnej, M.P. 2011, nr 93, poz. 953.

Zbiorcze sprawozdanie Gtównej Komisji Orzekającej za 2012 r., [online] http://www.mf.gov.pl/ documents/764034/1396184/sprawozdanie_GKO_2012.pdf.

\section{Literatura}

Adamczyk A., Zakres przedmiotowy odpowiedzialności majątkowej funkcjonariuszy publicznych za rażace naruszenie prawa, [online] http://m.ksiegarnia.lexisnexis.pl/gfx/lexisnexis/userfiles/files/zakres_przedmiotowy_odpowiedzialnosci_majatkowej_funkcjonariuszy_publicznych_za_razace_naruszenie_prawa.pdf.

Bagińska E., Odpowiedzialność funkcjonariuszy publicznych za rażace naruszenie prawa w świetle projektu ustawy o szczególnych zasadach odpowiedzialności funkcjonariuszy publicznych za rażace naruszenie prawa, „Zeszyty Prawnicze” 2009, nr 1.

Dąbrowski S., Opinia Krajowej Rady Sądownictwa z dnia 9 grudnia 2008 r. w przedmiocie poselskiego projektu ustawy o szczególnych zasadach odpowiedzialności funkcjonariuszy publicznych za rażace naruszenie prawa, druk nr 1407, Warszawa, 10 XII 2008, [online] http:// orka.sejm.gov.pl/Druki6ka.nsf/0/CC5A629F35ED310CC12575270043F51D/\$file /1407-001.pdf.

Drobny W., Mazuryk M., Zuzankiewicz P., Ustawa o stużbie cywilnej. Komentarz, Warszawa 2012.

Garlicki S., Piekarski M., Stelmachowski A., Odpowiedzialność cywilna za niedobory (manka), Warszawa 1962.

Gubała M., Paszka Ł., O niektórych proceduralnych aspektach odpowiedzialności dyscyplinarnej w stużbie cywilnej, „Przegląd Prawa Publicznego” 2012, nr 12.

Hajdys D., Naruszenie dyscypliny finansów publicznych jako przejaw patologii w finansach publicznych, [w:] Patologie w administracji publicznej, red. P. Suwaj, D. Kijowski, Warszawa 2009.

Itrich-Drabarek J., Uwarunkowania, standardy i kierunki zmian funkcjonowania stużby cywilnej $w$ Polsce na tle europejskim, Warszawa 2010.

Jachimowicz M., Charakterystyka ustawy z dnia 26 listopada 2010 r. o zmianie ustawy - Kodeks karny oraz ustawy o Policji, [online] http://pila.szkolapolicji.gov.pl/joomla/images/Zamowienia/Kwartalnik/Nr6-7/kk.pdf.

Jagielski J., Rączka K., Ustawa o stużbie cywilnej. Komentarz, Warszawa 2010.

Jędruszuk Ł., Odpowiedzialność majątkowa funkcjonariuszy publicznych za rażące naruszenie prawa - analiza praktyczna, „Temidium” 2011, nr 2.

Kasznica S., Polskie prawo administracyjne. Pojęcia i instytucje zasadnicze, Poznań 1947.

Kodeks pracy. Komentarz, red. W. Muszalski, Warszawa 2013.

Konstytucja Rzeczypospolitej Polskiej, 2 IV 1997, Dz.U. 1997, nr 78, poz. 483. 
Kosikowski C., Dyscyplina finansów publicznych oraz odpowiedzialnośćza jej naruszenie, [w:] Finanse publiczne i prawo finansowe, red. tenże, E. Ruśkowski, Warszawa 2007.

Kosikowski C., Odpowiedzialność za naruszenie dyscypliny finansów publicznych. Komentarz i przepisy, Warszawa 2000.

Kosikowski C., Szpringer Z., Finanse publiczne. Komentarz do ustawy z dnia 26 listopada 1998 r., Zielona Góra 2000.

Kościńska-Paszkowska A., Bolek T., Odpowiedzialność za naruszenie dyscypliny finansów publicznych - zmiana ustawy, „Kontrola Państwowa” 2012, nr 2.

Krajowa Izba Gospodarcza, Zasady odpowiedzialności funkcjonariuszy publicznych, Warszawa, 30 XI 2010, [online] http://www.kig.pl/informacje-prasowe/2210-zasady-odpowiedzialnosci-funkcjonariuszy-publiczny.html.

Kulesza M., Opinia odnośnie do poselskiego projektu ustawy o szczególnych zasadach odpowiedzialności funkcjonariuszy publicznych za naruszenie prawa i o zmianie innych ustaw, druk sejmowy nr 3484, Warszawa, 31 XII 2004, [online] http://orka.sejm.gov.pl/proc4.nsf/opisy/3484.htm.

Lachowski J., Przestępstwa przeciwko dziatalności instytucji państwowych oraz samorządu terytorialnego, [w:] Kodeks karny. Część szczególna, t. 2: Komentarz art. 222-316, red. M. Królikowski, R. Zawłocki, Warszawa 2013.

Lipiec-Warzecha L., Czy zawsze naruszenie dyscypliny finansowej jest szkodliwe dla finansów publicznych, [online] http://finansepubliczne.bdo.pl/component/content/article/163.pdf.

Lipiec-Warzecha L., Ustawa o odpowiedzialności za naruszenie dyscypliny finansów publicznych. Komentarz, Warszawa 2012.

Lipiec-Warzecha L., Zakaz petnienia funkcji zwiąanych z dysponowaniem środkami publicznymi-uwagi de lege lata, [w:] Problemy stanowienia i stosowania prawa finansowego w krajach Europy Środkowej i Wschodniej. Materiaty z konferencji naukowej w Grodnie w dniach 16-17 września 2006, Grodno 2006.

Lipiec-Warzecha L., Zakres odpowiedzialności za naruszenie dyscypliny finansów publicznych, [online] http://finansepubliczne.bdo.pl/component/content/article/163.pdf.

Łętowska E., Odpowiedzialność odszkodowawcza administracji, [w:] System prawa administracyjnego, t. 3, red. T. Rabska, J. Łętowski, Wrocław 1978.

Mroczka K., Wptyw polityki zarządzania zasobami ludzkimi w stużbie cywilnej na funkcjonowanie państwa, Warszawa 2015.

Muszalski W., Odpowiedzialność materialna pracowników, [w:] Kodeks pracy. Komentarz, red. tenże, Warszawa 2013.

Poradnik antykorupcyjny dla urzędników, Centralne Biuro Antykorupcyjne, Warszawa 2011.

Putalski W., Odpowiedzialność materialna pracowników, Gdańsk 1999.

Putalski W., Pracownicza odpowiedzialność odszkodowawcza. Praktyczny komentarz dla pracodawców, Warszawa 2006.

Rakoczy B., Matan A., Komentarz do art. 6, [w:] Odpowiedzialność majątkowa funkcjonariuszy publicznych za rażace naruszenie prawa. Komentarz, red. A. Bielska-Brodziak, Warszawa 2011.

Rakoczy B., Ustawa o odpowiedzialności majątkowej funkcjonariuszy publicznych. Komentarz, Warszawa 2012.

Rydlewski G., Stużba cywilna w Polsce. Przegląd rozwiąań na tle doświadczeń innych państw i podstawowe akty prawne, Warszawa 2001. 
Satko J., Glosa do wyroku SN z dnia 5 listopada 1997 r., V KKN 105/97. Teza nr 1, 14800/1, „Orzecznictwo Sądów Polskich” 1998, z. 6, poz. 117.

Stużba cywilna $w$ Polsce 1922-2012. Ciagtość $i$ zmiany $w$ aktach prawnych, oprac. J. Itrich-Drabarek, A. Filak, K. Mroczka, Warszawa 2012.

Stelmach-Młynarska A., Rażace naruszenie prawa jako przestanka odpowiedzialności majątkowej funkcjonariuszy publicznych, „Monitor Ubezpieczeniowy” 2012, nr 49, [online] http://rzu. gov.pl/publikacje/artykuly-pracownikow-i-wspolpracownikow/Anna_Stalmach_Mlynarska_Razace_naruszenie_prawa_jako_przeslanka_odpowiedzialnosci_majatkowej_funkcjonariuszy_publiczny_21009.

Suwaj P., Konflikt interesów w administracji publicznej, Warszawa 2009.

System odpowiedzialności za naruszenie dyscypliny finansów publicznych. Analiza funkcjonowania i propozycje zmian, Kancelaria Prezesa Rady Ministrów, Warszawa, 19 III 2010.

Szarek R., Czy odpowiedzialność majątkowa urzędników powinna mieć nowe uregulowanie prawne?, „Samorząd Terytorialny” 2010, nr 3.

Szczepaniak R., Odpowiedzialność majątkowa urzędników - czy niezbędna jest nowa regulacja prawna?, „Finanse Komunalne” 2009, nr 5.

Ślifirczyk M., O projekcie ustawy o szczególnych zasadach odpowiedzialności funkcjonariuszy publicznych za rażace naruszenie prawa, „Zeszyty Prawnicze” 2009, nr 1.

Śmigielska E., Reforma systemu wynagradzania w korpusie stużby cywilnej, „Zarządzanie Publiczne" 2010, nr 3(11).

Ura E., Odpowiedzialność prawna stużby publicznej w administracji rzadowej i samorzadu terytorialnego, [w:] Stużba publiczna. Stan obecny i oczekiwania, red. M. Stec, S. Płażek, Warszawa 2013.

Warkałło W., Odpowiedzialność odszkodowawcza. Funkcje, rodzaje, granice, Warszawa 1972.

Wincenciak M., Sankcje w prawie administracyjnym i procedura ich wymierzania, Warszawa 2008. Zieliński Z., Kierunki zmian systemu zarządzania zasobami ludzkimi w stużbie cywilnej, „Zarządzanie Zasobami Ludzkimi” 2010, nr 6.

Dr Kamil MROCZKA - doktor nauk społecznych, politolog, administratywista i praktyk zarządzania. Pracował w administracji rządowej m.in. jako kierownik oddziału zarządzania kadrami i zastępca dyrektora Biura Kadr i Organizacji w Mazowieckim Urzędzie Wojewódzkim w Warszawie, a także dyrektor Biura Kadr i Logistyki oraz Biura Dyrektora Generalnego w Ministerstwie Sprawiedliwości. Aktualnie zatrudniony na stanowisku dyrektora Biura Dyrektora Generalnego w Ministerstwie Finansów. Słuchacz programu Executive MBA prowadzonego w Międzynarodowym Centrum Zarządzania UW. Wykładowca w Instytucie Nauk Politycznych im. J. Karskiego oraz Instytucie Zarządzania i Inżynierii Produkcji PWSZ w Oświęcimiu i Instytucie Nauk Politycznych Uniwersytetu Warszawskiego. Specjalizuje się w zagadnieniach związanych z zarządzaniem w administracji publicznej, zarządzaniem zasobami ludzkimi, zarządzaniem publicznym oraz prawie urzędniczym. Jest autorem i współautorem kilkunastu artykułów i monografii odnoszących się do problematyki służby cywilnej, zarządzania i administracji publicznej. 